A C T A U N I V E R S I T A T I S N I C O L A I C C O P E R N I C I
DOI: http://dx.doi.org/10.12775/AUNC_ECON.2016.008

Pierwsza wersja złożona 15 czerwca $2016 \quad$ e-ISSN: 2392-1269

Końcowa wersja zaakceptowana 10 grudnia $2016 \quad$ p-ISSN: 2080-0339

Czestawa Pilarska*

\title{
PODATKOWE ASPEKTY ZWIĄZANE \\ Z PRZEPŁYWAMI BEZPOŚREDNICH INWESTYCJI ZAGRANICZNYCH W SKALI GLOBALNEJ
}

\begin{abstract}
$\mathrm{Z}$ arys treści. Artykuł porusza zagadnienia związane z przepływami bezpośrednich inwestycji zagranicznych (BIZ) w skali globalnej w latach 1990-2014. Zaprezentowano w nim strumienie i zasoby napływu i odpływu tych inwestycji z uwzględnieniem podziału na kraje rozwinięte, rozwijające się oraz transformujące swoje gospodarki. Szczególną uwagę poświęcono debacie, jaka toczy się wokół kwestii podatkowych związanych z działalnością korporacji transnarodowych (KTN), podejmujących BIZ. Podmioty te, dążąc do osiągnięcia wysokiej stopy zwrotu z inwestycji i maksymalizacji zysków, stosują praktyki, które przyczyniają się do zmniejszania wpływów budżetowych zarówno krajów przyjmujących, jak i macierzystych przez działania ukierunkowane na zmniejszanie podstawy opodatkowania i przesuwanie dochodów do krajów o niskich stawkach podatkowych, w celu optymalizacji podatkowej.
\end{abstract}

S łow a kluc zowe: bezpośrednie inwestycje zagraniczne, korporacje transnarodowe, gospodarka światowa, optymalizacja podatkowa.

K 1 a s y f i a c j a J E L: F21, F23, F38.

WSTĘP

Bezpośrednie inwestycje zagraniczne są tym zjawiskiem w gospodarce światowej, które rozwija się bardzo dynamicznie, jakkolwiek w latach 1990-2014 można było zaobserwować zarówno fazy przyspieszenia, jak i spo-

\footnotetext{
* Adres do korespondencji: Czesława Pilarska, Katedra Mikroekonomii, Uniwersytet Ekonomiczny w Krakowie, ul. Rakowicka 27, 31-510 Kraków, e-mail: pilarskc@uek.krakow.pl.
}

(C) 2016 Uniwersytet Mikołaja Kopernika. All rights reserved. http://www.aunc.ekonomia.umk.pl 
wolnienia tego procesu, co ściśle wiązało się z koniunkturą gospodarczą występującą na świecie. W czasie dobrej koniunktury wolumen inwestycji w postaci BIZ na ogół wzrastał, natomiast w okresie dekoniunktury, której towarzyszyło zwykle zwiększenie ryzyka na rynkach finansowych, inwestorzy odkładali w czasie realizację inwestycyjnych projektów, zwłaszcza typu greenfield, co przekładało się na spadek światowych przepływów tych inwestycji. Szczególnie dotkliwy był ostatni ekonomiczny i finansowy kryzys o zasięgu globalnym, którego nasilenie miało miejsce w latach 2008-2009, który doprowadził do załamania światowych strumieni inwestycji bezpośrednich.

Należy nadmienić, że światowe strumienie BIZ są również ściśle powiązane z przyspieszeniem procesów globalizacji i internacjonalizacji. W ostatnich latach znacznie wzrosło tempo integracji gospodarek narodowych i rynków. W ramach Światowej Organizacji Handlu (WTO) funkcjonuje obecnie 180 regionalnych porozumień handlowych (WTO, 2016). Swobodny przepływ kapitału i pracy, przesunięcie zakładów produkcyjnych z lokalizacji cechujących się wysokimi kosztami produkcji do krajów o niższych kosztach, stopniowe usuwanie barier handlowych, szybki rozwój technologii informacyjnych i telekomunikacyjnych, stale zwiększająca się rola zarządzania ryzykiem oraz wzrost znaczenia $\mathrm{w}$ działalności firm aktywów niematerialnych (intangible assets) i związany z tym rozwój, ochrona i wykorzystywanie własności intelektualnej - wszystkie te czynniki odegrały istotną rolę $\mathrm{w}$ sposobie zorganizowania i zarządzania współcześnie działających korporacji transnarodowych (OECD, 2013, s. 25). Spowodowało to odejście od modeli operacyjnych, charakterystycznych dla poszczególnych krajów w kierunku modeli globalnych opartych na zarządzaniu macierzowym ( $m a-$ trix management $)^{1}$ i zintegrowanych łańcuchach dostaw (supply chains), które łączą liczne funkcje na regionalnym lub globalnym poziomie. Ponadto z punktu widzenia funkcjonowania korporacji transnarodowych ważne jest również wzrastające znaczenie usług i produktów cyfrowych w światowej gospodarce, które mogą być dostarczane za pośrednictwem Internetu, co stwarza możliwości prowadzenia działalności produkcyjnej i biznesowej w różnych geograficznych lokalizacjach, które znajdują się w znacznej fi-

\footnotetext{
${ }^{1}$ Szerzej na temat zarządzania macierzowego, polegającego na tworzeniu w przedsiębiorstwie wielofunkcyjnych zespołów, składających się z osób $\mathrm{z}$ różnych działów, o różnych kompetencjach i mających różne specjalności i składających raporty nie tylko bezpośredniemu zwierzchnikowi, ale również kierownikowi realizowanego projektu, w kontekście działalności korporacji transnarodowych pisze K. Goś w niepublikowanej rozprawie doktorskiej pt. Efficiency considerations of matrix structures in multinational corporations (Goś, 2015). Zob. także opracowanie pt. The Matrix Management Organization Reloaded (Gottlieb, 2013).
} 
zycznej odległości od końcowych klientów (OECD, 2013, s. 25). Korporacje transnarodowe budują zatem swoje struktury poprzez dokonywanie inwestycji o transgranicznym charakterze (cross-border investment). Czynią to w sposób możliwie najbardziej efektywny z punktu widzenia kwestii podatkowych, z jednoczesnym uwzględnieniem potrzeb i ograniczeń operacyjnych. Podmioty te stają się coraz bardziej złożone. Składają się one z wielu powiązanych z firmą macierzystą filii i oddziałów (Jaworek, Kuzel, 2015, s. 58), usytuowanych w różnych krajach, zlokalizowanych na różnych kontynentach, powiązanych ze sobą $\mathrm{w}$ taki sposób, że każda $\mathrm{z}$ jednostek w ramach KTN z osobna lub wspólnie może wywierać znaczący wpływ na działalność innych, a w szczególności dzielić się z nimi wiedzą i zasobami (Kosztowniak, 2015, s. 103). R. Aggarwal i in. podkreślają, że w nowoczesnym środowisku biznesowym korporacje transnarodowe zwiększają swoją działalność ponad granicami poszczególnych krajów głównie przez eksport i import surowców naturalnych, półproduktów lub produktów finalnych, wykorzystywanie zagranicznego kapitału, zatrudnianie pracowników, stosowanie określonych procesów oraz przez organizowanie, koordynowanie i kontrolowanie zasobów w skali globalnej (Aggarwal i in., 2011, s. 557). Złożoność tych struktur, połączona $\mathrm{z}$ dokonywaniem przepływów wewnątrz korporacyjnych pomiędzy podmiotami zależnymi usytuowanymi w różnych miejscach na świecie, stwarza szansę wyboru najkorzystniejszych pod względem podatkowym lokalizacji i tym samym umożliwia zmniejszenie lub uniknięcie płacenia podatku od dochodów uzyskiwanych z podejmowanych inwestycji. Wielkość i kierunki przepływów BIZ pozostają zatem często pod wpływem podatkowych strategii realizowanych przez KTN.

Zjawisko polegające na zmniejszaniu (erozji) przez korporacje transnarodowe podstawy opodatkowania i przesuwaniu dochodów do jurysdykcji o niskich stawkach podatkowych, określane mianem BEPS (Base Erosion and Profit Shifting), ulega w gospodarce światowej systematycznemu nasileniu. Budzi to sprzeciw rządów poszczególnych krajów (szczególnie rozwijających się), gdyż praktyki stosowane przez KTN obniżają wpływy do budżetu i tym samym oddziałują negatywnie na poziom dobrobytu mieszkańców tych państw. Na problem ten, który w coraz większym stopniu ma charakter globalny, zwróciły uwagę także organizacje pozarządowe (non-governmental organisations - NGOs) oraz międzynarodowe, takie jak OECD czy UNCTAD (Agenda ONZ ds. Handlu i Rozwoju). Przeciwko optymalizacji podatkowej stosowanej przez KTN wypowiedzieli się również przedstawiciele najbogatszych państw świata, którzy stwierdzili, w opracowanej na szczycie grupy G20 deklaracji, który odbył się w Sankt Petersburgu w 2013 r., że problemy związane z unikaniem opodatkowania, szkodliwe 
praktyki oraz agresywne planowanie podatkowe muszą być rozwiązane. Ze względu na trudności ekonomiczne i społeczne, z którymi boryka się obecnie wiele krajów na świecie, priorytetem staje się doprowadzenie do sytuacji, w której wszyscy płatnicy podatków będą uczciwie wywiązywali się ze swoich zobowiązań. Według uczestników szczytu zyski powinny być opodatkowywane w tych krajach, w których prowadzona jest działalność gospodarcza, wytwarzane są produkty i gdzie w rzeczywistości powstaje nowa wartość (G20 Leaders'Declaration, 2013). Sprawa nie jest jednak prosta, bowiem zbyt restrykcyjne przepisy podatkowe mogą spowodować zmniejszenie aktywności inwestycyjnej prowadzonej przez korporacje transnarodowe $\mathrm{w}$ postaci bezpośrednich inwestycji zagranicznych, a inwestycje te są niezbędne dla zapewnienia globalnego zrównoważonego wzrostu i rozwoju w dhugim okresie.

Celem opracowania jest ukazanie tendencji występujących w globalnych przepływach bezpośrednich inwestycji zagranicznych w latach 1990-2014 oraz przedstawienie zagadnień związanych podatkowymi aspektami działalności KTN, które w bezpośredni sposób oddziałują zarówno na skalę, jak i kierunki tych inwestycji na świecie.

Metody wykorzystane w pracy badawczej obejmują studia literaturowe oraz analizę danych statystycznych. Bazę źródłową stanowią dane pochodzące z UNCTAD, Banku Światowego oraz WTO. Informacje dotyczące sposobów ograniczania BEPS zaczerpnięto $\mathrm{z}$ raportów sporządzonych przez OECD i Komisję Europejską.

W opracowaniu postawiono tezę, że rozmiary i kierunki przepływów BIZ we współczesnej gospodarce światowej w coraz większym stopniu zależą od strategii podatkowych realizowanych przez korporacje transnarodowe, ponieważ struktura i złożoność tych podmiotów oraz sposoby inwestowania zwiększają możliwości w zakresie unikania opodatkowania.

\section{ZNACZENIE, ROZMIARY I STRUKTURA BIZ W GOSPODARCE ŚWIATOWEJ}

Bezpośrednie inwestycje odgrywają istotną rolę w światowej gospodarce. Według Światowego Forum Ekonomicznego (World Economic Forum WEF) BIZ są kluczowym czynnikiem napędzającym (key driver) wzrost i dobrobyt w skali świata. Według WEF globalna gospodarka potrzebuje zwiększonych przepływów BIZ, ponieważ przyczyniają się one do poprawy efektywności w zakresie wykorzystania zasobów, tworzą nowe miejsca pracy oraz promują rozprzestrzenianie się wiedzy (WEF, 2013, s. 10). Z analiz ekonometrycznych wynika, że dzięki BIZ dochód krajów rozwiniętych wzrastał o 1,1\% rocznie szybciej w ciągu ostatnich dwóch dekad, natomiast 
w przypadku krajów rozwijających się było to $1,4 \%$ rocznie. Szacuje się, że światowy PKB jest obecnie o ponad $20 \%$ wyższy w zestawieniu z rokiem $1990 \mathrm{z}$ powodu ogromnej ekspansji światowych BIZ, którym towarzyszył transfer technologii, wyższe płace i ogólny rozwój (WEF, 2013, s. 11). Jednym z wyzwań stojących przed współczesnymi gospodarkami jest bezrobocie, które nasiliło się szczególnie po ostatnim kryzysie. O ile stopa bezrobocia w skali globalnej w 2007 r. kształtowała się zgodnie z danymi Banku Światowego (WB, 2016) na poziomie $5,5 \%$, to w 2009 r. było to $6,3 \%$ (dokładnie tyle, ile wynosiła w roku 1991). Z tego punktu widzenia ważne jest oddziaływanie BIZ na rynek pracy. Analizy przeprowadzone przez UNCTAD pokazują, że wzrost zatrudnienia związany z tymi inwestycjami był imponujący. Ilość zatrudnionych przez filie i oddziały korporacji transnarodowych na świecie wzrosła z $21 \mathrm{mln}$ osób w 1990 r. do $75 \mathrm{mln}$ osób w roku 2014. Korporacje te dzięki dokonywanym inwestycjom bezpośrednim osiągały także bardzo dobre wyniki ekonomiczne. Wartość sprzedaży wygenerowana przez zagraniczne oddziały (foreign affiliates) KTN wzrosła z 4723 mld USD w roku 1990 do 36356 mld USD w roku 2014. W tym samym przedziale czasu odnotowano także ponad pięciokrotny wzrost eksportu tych podmiotów z 1444 mld USD do 7803 mld USD. Zwiększyły się także dochody osiągane w latach 1990-2014 z tytułu BIZ. Wzrosły one z 82 mld USD do 1575 mld USD w przypadku zasobów napływu BIZ (inward FDI) oraz ze 128 mld USD do 1486 mld USD w odniesieniu do odpływu (outward FDI) tych inwestycji (UNCTAD, 2015a, s. 18).

Patrząc na światowe przepływy BIZ z perspektywy historycznej, tj. całego XX w., można stwierdzić, że największe przyspieszenie wystąpiło w ostatniej dekadzie tegoż wieku (Te Velde, 2006 s. 5). Było ono spowodowane $\mathrm{w}$ dużej mierze postępem w zakresie liberalizacji obowiązujących ograniczeń w międzynarodowym przepływie kapitału ${ }^{2}$ oraz szybkim tempem wzrostu odnotowywanym w różnych częściach świata (Warżała, 2013, s. 171). Od początku lat dziewięćdziesiątych widoczny był znaczący wzrost zainteresowania inwestorów nowymi rynkami, szczególnie zaś w dynamicz-

\footnotetext{
${ }^{2}$ Pomiędzy rokiem 1991 a 2000 wprowadzono łącznie 1185 zmian w przepisach dotyczących BIZ, z czego 1121 było bezpośrednio ukierunkowanych na stworzenie bardziej sprzyjających warunków dla tych inwestycji. Polegały one przede wszystkim na zwiększeniu liberalizacji, wzmocnieniu funkcjonowania rynków i zapewnieniu konkurencji rynkowej oraz zwiększeniu ilości zachęt (incentives). W samym tylko $2000 \mathrm{r}$. wprowadzonych zostało 150 zmian w zakresie prawa i regulacji przez 69 krajów na świecie. W okresie tym szybko wzrastała również liczba zawieranych dwustronnych traktatów o popieraniu i ochronie inwestycji (Bilateral Investment Treaty). Do końca 2000 r. zawarto łącznie 1941 tego typu porozumień (UNCTAD, 2000, s. 6).
} 
nie rozwijających się krajach Azji i Pacyfiku oraz częściowo Ameryce Południowej, gdzie w 1994 r. napływ kapitału stanowił około 40\% poziomu światowego. Dodatkowym bodźcem zachęcającym do inwestowania było nieprzerwane i wysokie tempo wzrostu w latach 90. XX w., jakie odnotowywała największa gospodarka świata - Stany Zjednoczone. Jak wynika m.in. z raportu opracowanego przez OECD, podstawową przyczyną szybkiego rozwoju amerykańskiej gospodarki w tamtym okresie było oparcie jej fundamentów na wiedzy, przy jednoczesnym szybkim rozwoju technologii informacyjnych i komunikacyjnych (OECD, 2001). Przepływom BIZ w skali globalnej sprzyjało także rozpoczęcie procesów transformacji i otwarcie się na świat gospodarek krajów Europy Srodkowo-Wschodniej (EŚW). Należy zaznaczyć, że do dzisiaj państwa te stanowią atrakcyjną lokalizację dla inwestorów zagranicznych ${ }^{3}$.

To wszystko sprawiło, że począwszy od $1992 \mathrm{r}$. nieprzerwanie do 2000 r. przepływy bezpośrednich inwestycji zagranicznych mierzone w skali światowej odnotowywały trend wzrostowy. Tendencja ta nie uległa zmianie nawet na skutek kryzysu finansowego, jaki miał miejsce w drugim półroczu 1997 r. w krajach azjatyckich. Zarówno strumienie, jak i zasoby BIZ na świecie wzrastały zatem nieprzerwanie przez 9 lat z rzędu. O tym jak duża była dynamika tego zjawiska świadczył fakt, że przepływy BIZ rosły szybciej niż tempo wzrostu światowego PKB i handlu jednocześnie.

Załamanie tendencji wzrostowej $\mathrm{w}$ zakresie BIZ nastąpiło dopiero w 2001 r. Globalne strumienie napływu i odpływu tych inwestycji zmniejszyły się w tymże roku o blisko 50\%. Było to związane z kryzysem w Stanach Zjednoczonych, wywołanym pęknięciem „bańki internetowej” (dotcom bubble). Gwałtowny spadek cen akcji spółek technologicznych w marcu 2000 r. w USA sprawił, że jak wynika z szacunków przeprowadzonych przez analityków JP Morgan, w ciągu zaledwie kwartału wiele firm sektora IT straciło pomiędzy 10 a $30 \mathrm{mln}$ USD i część z nich musiała ogłosić upadłość (What Did We Learn From the Dotcom..., 2015). Głębokie zachwiania kursów giełdowych i kryzys firm internetowych (dotcom crisis) udało się amerykańskiej gospodarce przezwyciężyć dzięki poluzowaniu polityki pieniężnej i regulacji dotyczących rynku kredytowego.

Załamanie w $2001 \mathrm{r}$. w światowych przepływach BIZ, którego główną przyczynę o czym wspomniano stanowił kryzys dotcomów, okazało się krót-

\footnotetext{
${ }^{3}$ Jak wynika z badań przeprowadzonych przez Ernst \& Young region EŚW znajdował się w 2015 r. na czwartym miejscu (po krajach Europy Zachodniej, Ameryce Północnej i Chinach) pod względem atrakcyjności do realizowania projektów inwestycyjnych (EY'attractiveness survey..., 2015, s. 2).
} 
kookresowe. Już bowiem w 2003 r. w przypadku strumienia odpływu odnotowano ponowny wzrost tych inwestycji w skali globalnej. W odniesieniu do strumieni napływu poprawa wystąpiła rok później.

Tym razem jednak tendencja wzrostowa była nieco krótsza. Po osiągnięciu przez BIZ historycznie najwyższego poziomu w 2007 r. (1 871,7 mld USD), w kolejnych latach odnotowano ponowne załamanie związane tym razem z globalnym kryzysem finansowym. Instrumenty, które zastosowano dla ratowania amerykańskiej gospodarki, aby przezwyciężyć negatywne skutki kryzysu dotcomów w postaci obniżki stóp procentowych (stopy te zmniejszyły się w USA w ciągu trzech lat o 5,5 p. proc. W połowie $2000 \mathrm{r}$. wynosiły one 6,5 proc., natomiast w czerwcu 2003 r. po kolejnych obniżkach przeprowadzonych przez FED zaledwie 1 proc.) spowodowały powstanie kolejnej bańki spekulacyjnej, tym razem dotyczyła ona rynku nieruchomości. Niski poziom stóp procentowych w USA zachęcił Amerykanów do zaciągania kredytów, których banki i instytucje finansowe chętnie udzielały w tamtym okresie, gdyż złagodzono regulacje na rynku kredytów hipotecznych. W efekcie tych działań rozwinął się rynek kredytów hipotecznych subprime - czyli kredytów dla osób o podwyższonym ryzyku kredytowym. Zbyt liberalna polityka w zakresie przyznawania kredytów doprowadziła do nadmiernego zadłużania się banków i innych instytucji finansowych, a także nadmiernego rozwoju inżynierii finansowej w tych podmiotach, prowadzącej do powstania skomplikowanych i trudnych do wyceny instrumentów finansowych. Konsekwencją błędów popełnionych w sferze banków (bank failures) było to, że gospodarka amerykańska w 2007 r. ponownie stanęła w obliczu recesji. Jej skutki okazały się jednak znacznie poważniejsze niż miało to miejsce w 2001 r. Zakłócenia zachodzące w systemie finansowym USA przeniosły się bowiem szybko do sfery realnej tej gospodarki, a następnie za pomocą różnych kanałów (w tym bezpośrednich inwestycji zagranicznych) rozprzestrzeniły się na wiele innych krajów na świecie, doprowadzając do kryzysu w wymiarze globalnym (Pilarska, 2013, s. 44).

Efektem zawirowań na światowych rynkach finansowych był gwałtowny spadek strumieni inwestycji bezpośrednich w latach 2008-2009. W $2008 \mathrm{r}$. globalne strumienie napływu BIZ (global FDI inflows) zmniejszyły się o 382 mld USD (spadek o 20,41\%), natomiast odpływu (global FDI outflows) o 436 mld USD (spadek o 20,47\%). Z kolei w 2009 r. było to odpowiednio: 303 mld USD (spadek o 20,35\%) i 593 mld USD (spadek o 34,98\%).

Lata 2010-2014, na które przypadało pokryzysowe ożywienie, charakteryzowały się dużą zmiennością. Co prawda w przedziale czasowym 2010-2011 udało się w pewnym zakresie odbudować wielkość światowych stru- 
mieni BIZ, jednakże w 2012 i 2014 r. ponownie odnotowywano spadki. W 2012 r. strumień odpływu BIZ zmniejszył się w skali globalnej o ponad 19\%, natomiast w $2014 \mathrm{r}$. o ponad 16\% zmniejszyły się z kolei strumienie napływu tych inwestycji (tabela 1 ).

Tabela 1. Strumienie i zasoby napływu i odpływu BIZ na świecie w latach 1990-2014

\begin{tabular}{|c|c|c|c|c|c|c|c|c|}
\hline \multirow[t]{2}{*}{ Lata } & \multicolumn{2}{|c|}{$\begin{array}{c}\text { Strumienie } \\
\text { napływu BIZ } \\
\text { (FDI inflows) } \\
\end{array}$} & \multicolumn{2}{|c|}{$\begin{array}{c}\text { Strumienie } \\
\text { odpływu BIZ } \\
\text { (FDI outflows) }\end{array}$} & \multicolumn{2}{|c|}{$\begin{array}{c}\text { Zasoby } \\
\text { napływu BIZ } \\
\text { (FDI inward stock) }\end{array}$} & \multicolumn{2}{|c|}{$\begin{array}{c}\text { Zasoby } \\
\text { odpływu BIZ } \\
\text { (FDI outward stock) }\end{array}$} \\
\hline & $\begin{array}{l}\text { w mld } \\
\text { USD }\end{array}$ & $w \%$ & w mld USD & w \% & w mld USD & w \% & w mld USD & w \% \\
\hline 1990 & 204,9 & - & 243,9 & - & 2 197, 8 & - & 2253,9 & - \\
\hline 1991 & 154,1 & $-24,79$ & 198,9 & $-18,45$ & 2472,9 & 12,52 & 2527,5 & 12,14 \\
\hline 1992 & 163,0 & 5,78 & 203,8 & 2,46 & 2495,5 & 0,91 & 2539,4 & 0,47 \\
\hline 1993 & 220,1 & 35,03 & 236,3 & 15,95 & 2700,7 & 8,22 & 2929,5 & 15,36 \\
\hline 1994 & 254,9 & 15,81 & 285,4 & 20,78 & 2965,6 & 9,81 & 3293,8 & 12,44 \\
\hline 1995 & 341,5 & 33,97 & 356,7 & 24,98 & 3566,3 & 20,26 & 3992,8 & 21,22 \\
\hline 1996 & 388,7 & 13,82 & 392,3 & 9,98 & 4136,1 & 15,98 & 4553,3 & 14,04 \\
\hline 1997 & 481,2 & 23,80 & 467,4 & 19,14 & 4723,6 & 14,20 & 5257,2 & 15,46 \\
\hline 1998 & 692,3 & 43,87 & 681,0 & 45,70 & 5920,4 & 25,34 & 6246,9 & 18,83 \\
\hline 1999 & 1076,3 & 55,47 & 1077,1 & 58,16 & 7090,9 & 19,77 & 7147,8 & 14,42 \\
\hline 2000 & 1363,2 & 26,66 & 1166,1 & 8,26 & 7202,3 & 1,57 & 7298,2 & 2,10 \\
\hline 2001 & 684,1 & $-49,82$ & 584,0 & $-49,92$ & 7045,6 & $-2,18$ & 7005,9 & $-4,01$ \\
\hline 2002 & 591,4 & $-13,55$ & 491,4 & $-15,86$ & 7060,0 & 0,20 & 7272,6 & 3,81 \\
\hline 2003 & 552,0 & $-6,66$ & 532,0 & 8,26 & 8752,2 & 23,97 & 9123,4 & 25,45 \\
\hline 2004 & 682,7 & 23,68 & 887,6 & 66,84 & 10191,5 & 16,45 & 10741,9 & 17,74 \\
\hline 2005 & 927,4 & 35,84 & 795,9 & $-10,33$ & 10982,9 & 7,77 & 11702,3 & 8,94 \\
\hline 2006 & 1393,2 & 50,23 & 1344,5 & 68,93 & 13587,9 & 23,72 & 14693,4 & 25,56 \\
\hline 2007 & 1871,7 & 34,35 & 2129,9 & 58,42 & 17111,6 & 25,93 & 18252,4 & 24,22 \\
\hline 2008 & 1489,6 & $-20,41$ & 1693,9 & $-20,47$ & 14979,4 & $-12,46$ & 15844,4 & $-13,19$ \\
\hline 2009 & 1186,4 & $-20,35$ & 1101,3 & $-34,98$ & 17610,0 & 17,56 & 18756,9 & 18,38 \\
\hline 2010 & 1328,1 & 11,94 & 1366,1 & 24,04 & 19607,4 & 11,34 & 20414,1 & 8,84 \\
\hline 2011 & 1563,7 & 17,74 & 1587,4 & 16,20 & 20441,7 & 4,26 & 21015,3 & 2,95 \\
\hline 2012 & 1402,9 & $-10,28$ & 1283,7 & $-19,13$ & 22073,2 & 7,98 & 22527,2 & 7,19 \\
\hline 2013 & 1467,2 & 4,58 & 1305,9 & 1,73 & 26034,9 & 17,95 & 25975,0 & 15,31 \\
\hline 2014 & 1228,3 & $-16,28$ & 1354,0 & 3,68 & 26038,8 & 0,01 & 25874,8 & $-0,39$ \\
\hline
\end{tabular}

Źródło: opracowanie własne na podstawie danych UNCTAD, (UNCTAD, 2015b).

Pomimo znacznych fluktuacji zachodzących w światowych przepływach inwestycji bezpośrednich i tego, że w 2014 r. były one znacząco niższe od najwyższych poziomów osiągniętych w roku 2007, należy podkreślić, że w ciągu 25 lat wartość strumienia napływu i odpływu światowych BIZ zwiększyła się prawie sześciokrotnie. W przypadku zaś wartości zasobów napływu i odpływu był to wzrost ponad jedenastokrotny. 
Należy zaznaczyć, że w latach 1990-2014 systematycznie wzrastał także udział bezpośrednich inwestycji w PKB (UNCTAD, 2015b). O ile w $1990 \mathrm{r}$. udział globalnych zasobów napływu BIZ w produkcie krajowym brutto wynosił $9,9 \%$, to w 2014 r. było to $33,6 \%$. Na podobnym poziomach kształtowały się także udziały globalnych zasobów odpływu BIZ (odpowiednio $10,3 \%$ i $33,7 \%)$.

Przewiduje się, że w 2015 r. udziały globalnych zasobów BIZ w PKB będą znacznie wyższe w porównaniu do roku 2014, ponieważ szacunkowe dane zawarte w raporcie pt. „Global Investment Trends Monitor” wskazują na silny (36\%) wzrost światowych strumieni napływu BIZ (UNCTAD, 2016, s. 1). Oznacza to, że wartość światowego strumienia BIZ w 2015 r. wynosząca 1,7 biliona USD będzie na najwyższym poziomie od czasu globalnego ekonomicznego i finansowego kryzysu z lat 2008-2009. Zwiększenie zainteresowania podejmowaniem BIZ przez inwestorów w $2015 \mathrm{r}$. wynikało w dużej mierze z przewidywanej poprawy klimatu inwestycyjnego w $2015 \mathrm{r}$. w porównaniu $\mathrm{z}$ rokiem $2014^{4}$.

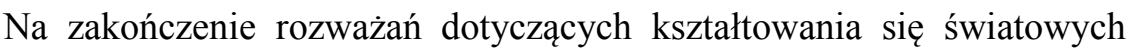
przepływów BIZ warto przyjrzeć się także ich strukturze. Analizując 25 letni

\footnotetext{
${ }^{4}$ Badania przeprowadzone UNCTAD wśród 80 korporacji transnarodowych pokazały, że poziom optymizmu wśród inwestorów wzrósł z 26\% w roku 2014 r. do 46\% w 2015 r. Pozytywna ocena klimatu inwestycyjnego była wsparta wzrostem zaufania, że ożywienie w gospodarce światowej będzie kontynuowane (w 2014 r. stopa wzrostu globalnego PKB wynosiła 2,48 proc. i była wyższa o 0,2 p. proc. w odniesieniu do roku 2013). Respondenci w badaniu tym wskazali także pozytywne i negatywne czynniki, które będą miały wpływ na przepływy globalnych BIZ w średnim okresie. Wśród pozytywnych czynników znalazły się kolejno: poziom rozwoju amerykańskiej gospodarki, warunki ekonomiczne występujące w państwach BRICS i innych wschodzących gospodarkach, a także sytuacja ekonomiczna występująca w krajach Unii Europejskiej (UE-28). Należy podkreślić, że kondycja gospodarcza państw Wspólnoty znajdowała się rok wcześniej na liście głównych obaw. Do czynników pozytywnie oddziałujących na światowe przepływy BIZ zaliczono również procesy związane z outsourcingiem i offshoringiem, integracją regionalną, a także zmiany w systemach opodatkowania przedsiębiorstw (corporate tax regimes). Jednocześnie inwestorzy wskazali na zagrożenia, które zwiększają niepewność wśród inwestorów i prowadzą do pogorszenia klimatu inwestycyjnego na świecie. Największe obawy w tym zakresie związane były z ryzykiem i czynnikami o charakterze politycznym, takimi jak: stosowanie praktyk protekcjonistycznych w handlu czy wysokość długu publicznego. Oprócz tego inwestorzy obawiali się katastrof naturalnych, wzrostu protekcjonizmu inwestycyjnego, kwestii związanych z terroryzmem, stosowania niestandardowych rozwiązań $\mathrm{w}$ polityce pieniężnej w postaci luzowania ilościowego (quantitative easing), a także monitorowania BEPS. Fakt, że czynniki o charakterze politycznym (w dużym stopniu związane z zadłużeniem poszczególnych krajów) zdominowały listę zagrożeń, świadczy według autorów badania o tym, że inwestorzy obawiają się o podstawy, na których zostało osiągnięte ożywienie gospodarcze, a także jego trwałość w dłuższej perspektywie (UNCTAD, 2014, s. 3-4).
} 
okres światowych przepływów inwestycji bezpośrednich można stwierdzić, że przez pierwszych 18 lat, tj. do 2007 r., dominującą rolę w tych przepływach odgrywały kraje rozwinięte. Ich udział w globalnym strumieniu napływu BIZ kształtował się w 2007 r. na poziomie 67\%, natomiast odpływu 85\%. Po 2007 r. udziały tej grupy krajów zaczęły w światowych BIZ stopniowo maleć i w 2014 r. strumienie napływu wynosiły już tylko $41 \%$, natomiast odpływu $-61 \%$ (tabela 2 ). Wśród państw rozwiniętych największe znaczenie w całym okresie analizy miały kraje tzw. Triady, która obejmuje Stany Zjednoczone, Japonię oraz państwa Unii Europejskiej. W początkowym okresie, tj. w 1990 r., udział Triady w strumieniu napływu BIZ do krajów rozwiniętych wynosił $86 \%$, odpływu zaś $93 \%$. W przypadku strumieni napływu udział ten rekordową wartość $(98,6 \%)$ osiągnął w 2005 r., co było w dużej mierze efektem rozszerzenia Unii Europejskiej o 10 nowych państw członkowskich w 2004 r. W ostatnim roku przyjętym do analizy, tj. 2014, udział Triady w napływie BIZ do krajów rozwiniętych wynosił 70,6\%, natomiast odpływu był znacznie wyższy, gdyż kształtował się na poziomie $88,8 \%$.

W grupie krajów Triady w 2014 r. zarysowały się następujące tendencje:

- Stany Zjednoczone były największym inwestorem. Koncerny amerykańskie zainwestowały poza granicami kraju 336,9 mld USD (o 56,8 mld USD więcej niż łącznie 28 krajów UE i o 223,3 mld USD więcej od Japonii),

- UE przodowała natomiast w przyjmowaniu BIZ, przyciągając w 2014 r. kapitał o wartości 257,6 mld USD, tj. ponad 2 i pół razy więcej niż USA. Spośród krajów Wspólnoty najwięcej kapitału w postaci BIZ przyciągnęły kolejno: Wielka Brytania 72,2 mld USD, Holandia 30,3 mld USD oraz Hiszpania 22,9 mld USD.

- w 2014 r. gospodarka japońska zainwestowała na zagranicznych rynkach ponad 54 razy więcej kapitału niż sama przyjęła.

Analizując strukturę rozdysponowania BIZ na świecie należy zaznaczyć, że od początku lat 90. XX w. wyraźnie wzrastało znaczenie krajów rozwijających się $\mathrm{w}$ światowych przepływach BIZ. Szczególnie widoczny był wzrost zainteresowania inwestorów zagranicznych krajami Azji Wschodniej (Chiny, Hongkong), Azji Południowo-Wschodniej (Singapur, Tajlandia, Malezja i Indonezja) oraz Azji Południowej (Indie). Udział strumienia napływu BIZ do krajów rozwijających się w wartości globalnego strumienia wzrósł z 16,9\% w 1990 r. do 38,6\% w roku 1997. W latach 1998-2000 odnotowano zmniejszenie napływu BIZ do tej grupy krajów, co było spowodowane w głównej mierze kryzysem finansowym, który dotknął w 2007 r. państwa azjatyckie. W 2000 r. udział krajów rozwijających się w światowych BIZ 
wynosił zaledwie 17\%. W $2001 \mathrm{r}$. inwestorzy ponownie zainteresowali się państwami azjatyckim. Silny impuls do powrotu do tego regionu świata dało inwestorom przystąpienie Chin do Światowej Organizacji Handlu (WTO) w $2001 \mathrm{r}$. W literaturze przedmiotu podkreśla się, że istnieją dowody potwierdzające efekt przekierowania BIZ wywołany przystąpieniem Chin do WTO (CASE, 2003, s. 18). Przystąpienie Chin do tej organizacji zwiększyło bowiem zaufanie inwestorów zagranicznych $\mathrm{w}$ zakresie zapewnienia odpowiednich regulacji i egzekwowanie prawa, co przełożyło się na większą gotowość do podejmowania inwestycji na obszarze tego kraju (Thorbecke, Salike, 2013, s. 7), szczególnie przez inwestorów japońskich ${ }^{5}$. Ponadto wzrost zainteresowania chińską gospodarką przez inwestorów zagranicznych wynikał także z wysokiego tempa wzrostu osiąganego przez ten kraj (w latach 2003-2006 tempo wzrostu chińskiego PKB przekraczało 10\%, a w 2007 r. osiągnęło wartość 14,2\%). Zapoczątkowany w 2001 r. trend wzrostowy dotyczący zwiększania udziału napływu BIZ do krajów rozwijających się z pewnymi wahaniami utrzymał się do 2014 r. Należy podkreślić, że wysoki trend wzrostowy $\mathrm{w}$ przypadku krajów rozwijających się utrzymywał się również w ostatnich latach w przypadku odpływu BIZ, choć na początku lat 90. strumienie napływu BIZ do tej grupy krajów znacznie przewyższały strumienie odpływu tych inwestycji. W 2014 r. firmy z krajów rozwijających się (szczególnie Chin i specjalnego regionu administracyjnego tego kraju Hongkongu) zainwestowały w postaci BIZ kapitał o wartości 468,1 mld USD, tj. ponad 35 razy więcej w porównaniu z rokiem 1990. Udział krajów rozwijających się w światowych strumieniach odpływu BIZ wzrósł z 5,4\% w roku 1990 do 34,6\% w roku 2014.

Analizując różnice występujące pomiędzy napływem BIZ do krajów rozwiniętych i rozwijających się, można stwierdzić, że największe dysproporcje były widoczne w 1990 r. oraz w latach 1998-2000. W roku 1990 napływ BIZ do krajów rozwiniętych był o 66,2 p. proc. wyższy od napływu tych inwestycji do krajów rozwijających się. W latach 1998-2000 było to odpowiednio: 47,9 p. proc., 59,2 p. proc. i 65,5 p. proc. Od 2000 r. różnica ta zaczęła się stopniowo zmniejszać. Po 2007 r. wynosiła już mniej niż 16 p. proc., a w 2014 r. tendencja ta uległa odwróceniu. Po raz pierwszy w ciągu 25 lat napływ BIZ do krajów rozwijających się był wyższy (o 14,9 p. proc.) w porównaniu z krajami rozwiniętymi. W 2014 r. Chiny

\footnotetext{
${ }^{5}$ Badania przeprowadzone w tym okresie przez Japoński Bank Współpracy Międzynarodowej (Japan Bank for International Cooperation - JBIC) wykazały, że odsetek japońskich KTN, które wskazały Chiny jako jedną z dziesięciu najbardziej atrakcyjnych lokalizacji zwiększył się w 2001 r. do 82\%, w porównaniu z 65\% w roku 2000 (UNCTAD, 2002, s. 44).
} 
(z udziałem 10,4\%) stały się także największym importerem BIZ na świecie, przyciągając kapitał o wartości 129 mld USD i wyprzedzając kolejno: Hongkong (103 mld USD), Stany Zjednoczone (93 mld USD), Wielką Brytanię (72 mld USD), Singapur (68 mld USD) oraz Brazylię (62 mld USD).

Tabela 2. Udział procentowy poszczególnych grup krajów w strumieniach napływu i odpływu bezpośrednich inwestycji zagranicznych w gospodarce światowej w latach 1990-2014

\begin{tabular}{|c|c|c|c|c|c|c|c|c|c|c|c|c|}
\hline \multirow{2}{*}{$\begin{array}{l}\text { Wyszczegól- } \\
\text { nienie }\end{array}$} & 1990 & 1997 & 1998 & 2000 & 2001 & 2004 & 2005 & 2007 & 2008 & 2012 & 2013 & 2014 \\
\hline & \multicolumn{12}{|c|}{ Świat } \\
\hline napływ BIZ & 100 & 100 & 100 & 100 & 100 & 100 & 100 & 100 & 100 & 100 & 100 & 100 \\
\hline \multirow{2}{*}{ odpływ BIZ } & 100 & 100 & 100 & 100 & 100 & 100 & 100 & 100 & 100 & 100 & 100 & 100 \\
\hline & \multicolumn{12}{|c|}{ Kraje rozwinięte } \\
\hline napływ BIZ, & 83,1 & 59,4 & 73,5 & 82,5 & 67,4 & 57,1 & 61,0 & 67,1 & 53,0 & 48,4 & 47,5 & 40,6 \\
\hline w tym Triada & 71,2 & 52,3 & 66,9 & 74,0 & 60,3 & 49,9 & 60,1 & 55,4 & 42,9 & 38,2 & 38,6 & 28,7 \\
\hline odpływ BIZ, & 94,6 & 85,3 & 93,5 & 92,1 & 89,6 & 85,8 & 83,2 & 85,0 & 80,3 & 68,0 & 63,8 & 60,8 \\
\hline \multirow[t]{2}{*}{ w tym Triada } & 87,7 & 74,4 & 84,7 & 83,0 & 78,4 & 75,7 & 74,4 & 77,5 & 69,6 & 58,5 & 57,4 & 54,0 \\
\hline & \multicolumn{12}{|c|}{ Kraje rozwijające się } \\
\hline $\begin{array}{c}\text { napływ BIZ, } \\
\text { w tym: }\end{array}$ & 16,9 & 38,6 & 25,5 & 17,0 & 31,5 & 38,7 & 35,6 & 28,2 & 39,3 & 45,6 & 45,7 & 55,5 \\
\hline Chiny, & 1,7 & 9,4 & 6,6 & 3,0 & 6,9 & 8,9 & 7,8 & 4,5 & 7,3 & 8,6 & 8,4 & 10,4 \\
\hline Hongkong & 1,6 & 2,4 & 2,0 & 4,0 & 4,2 & 4,3 & 3,7 & 3,1 & 3,9 & 5,0 & 5,1 & 8,4 \\
\hline $\begin{array}{c}\text { odpływ BIZ, } \\
\text { w tym: }\end{array}$ & 5,4 & 14,0 & 6,3 & 7,6 & 10,0 & 12,7 & 13,8 & 12,7 & 16,2 & 27,8 & 29,2 & 34,6 \\
\hline Chiny, & 0,3 & 0,5 & 0,4 & 0,1 & 1,2 & 0,6 & 1,5 & 1,2 & 3,3 & 6,8 & 7,7 & 8,6 \\
\hline \multirow[t]{2}{*}{ Hongkong } & 1,0 & 5,2 & 2,4 & 4,6 & 3,1 & 4,9 & 3,4 & 3,0 & 2,9 & 6,5 & 6,2 & 10,5 \\
\hline & \multicolumn{12}{|c|}{ Kraje będące $w$ procesie transformacji } \\
\hline napływ BIZ, & 0,03 & 2,0 & 1,0 & 0,4 & 1,1 & 4,3 & 3,4 & 4,7 & 7,8 & 6,1 & 6,8 & 3,9 \\
\hline w tym Rosja & - & 1,0 & 0,4 & 0,2 & 0,4 & 2,3 & 1,7 & 3,0 & 5,0 & 3,6 & 4,7 & 1,7 \\
\hline odpływ BIZ, & 0,0 & 0,7 & 0,2 & 0,3 & 0,4 & 1,6 & 2,4 & 2,4 & 3,5 & 4,2 & 7,0 & 4,7 \\
\hline w tym Rosja & - & 0,7 & 0,2 & 0,3 & 0,4 & 1,6 & 2,2 & 2,1 & 3,3 & 3,8 & 6,6 & 4,2 \\
\hline
\end{tabular}

Źródło: opracowanie własne na podstawie danych UNCTAD, http://unctadstat.unctad.org (19.04. 2016).

W latach 1990-2014 wzrastał także stopniowo udział krajów transformujących swoje gospodarki w światowych przepływach BIZ, jakkolwiek był on znacznie mniejszy w porównaniu $\mathrm{z}$ absorpcją kapitału przez kraje rozwijające się. W 1990 r. kraje transformujące (transition countries) charakteryzowały się znikomym udziałem w strumieniu napływu BIZ na świecie wynoszącym zaledwie $0,03 \%$. Udział ten wzrósł do najwyższego $(7,8 \%)$ poziomu w 2008 r., a następnie zmniejszał się. W 2014 r. udział ten wynosił $3,9 \%$. Wzrosty oraz spadki udziału krajów transformujących się w światowych przepływach BIZ zależały w głównej mierze od kształtowania się sy- 
tuacji w Rosji - największego odbiorcy inwestycji bezpośrednich w tej grupie krajów. W 2014 r. udział rosyjskiej gospodarki wśród krajów transformujących wynosił $43,6 \%$, rok wcześniej było to $69,5 \%$.

Z punktu wiedzenia dalszej analizy, dotyczącej kwestii podatkowych, ważna jest także struktura branżowa globalnych BIZ. Począwszy od $1990 \mathrm{r}$. obserwuje się wzrost znaczenia usług $\mathrm{w}$ międzynarodowej przestrzeni inwestycyjnej jako długookresowego strukturalnego trendu. Udział usług w światowych zasobach BIZ pomiędzy rokiem 1990 a 2012 wzrósł o 14 p. proc (z 49\% do 63\%), przy jednoczesnym spadku udziału przemysłu o 15 p. proc. (z $41 \%$ do 26\%). Udział pierwszego sektora (primary sektor) obejmującego rolnictwo i przemysł wydobywczy kształtował się na stabilnym poziomie ok. 7\% (UNCTAD, 2015a, s. 12). Postępująca zmiana sektorowa w globalnych przepływach BIZ odzwierciedla analogiczną tendencję w udziale poszczególnych sektorów w tworzeniu PKB. Ponadto zwiększenie światowych strumieni BIZ było w dużym stopniu wynikiem wzrastającej liberalizacji, mającej miejsce szczególnie w tych branżach, które wcześniej były niedostępne dla inwestorów zagranicznych, takich jak finanse czy telekomunikacja. Zmiana struktury branżowej strumieni BIZ dotyczyła zarówno krajów rozwiniętych, jak i rozwijających się. Wśród krajów rozwijających się na szczególną uwagę zasługują kraje azjatyckie, będące motorem rozwoju usług związanych z inwestycjami bezpośrednimi. Szacuje się, że wartość zasobu BIZ w sektorze usług wzrosła w Azji i Oceanii z 800 mld USD w 2001 r. do 3,5 biliona USD 2012 r., co stanowiło $80 \%$ całościowego wzrostu BIZ związanych z usługami w krajach rozwijających się. Podkreślić należy również zwiększający się udział usług w zasobach napływu BIZ do krajów afrykańskich. W 2014 r. udział ten kształtował się na poziomie 48\% (UNCTAD, 2015a, s. 32).

Rosnące zainteresowanie usługami (pomimo że na pierwszym miejscu uplasował się sektor wydobywczy) potwierdzają także dane zgromadzone przez FDI Markets (centralny bank informacji na temat globalizacji działalności biznesowej, będący częścią FDI Intelligence), dotyczące wyboru przez inwestorów zagranicznych kluczowych sektorów w ramach BIZ na świecie. Głównymi sektorami przyjmującymi kapitał w formie BIZ w skali globalnej od lutego 2014 r. do lutego 2016 r. były w kolejności sektory takie, jak: węgiel, ropa i gaz z wartością zainwestowanego kapitału na poziomie 176,4 mld USD, pośrednictwo nieruchomości (168,3 mld USD), alternatywne/odnawialne źródła energii (113,4 mld USD) oraz komunikacja (83,0 mld USD).

W tabeli 3 ukazano pełny zestaw składający się z 10 kluczowych sektorów wybieranych przez inwestorów zagranicznych podejmujących BIZ 
z uwzględnieniem wartości zainwestowanego kapitału, liczby zrealizowanych projektów inwestycyjnych, liczby przedsiębiorstw oraz utworzonych miejsc pracy.

Tabela 3. Dziesięć kluczowych sektorów (Top 10 sectors) wybieranych przez inwestorów zagranicznych podejmujących BIZ w latach 2014-2016 (luty)

\begin{tabular}{|c|c|c|c|c|c|c|c|c|}
\hline \multirow{3}{*}{$\begin{array}{l}\text { Lp. } \\
1 .\end{array}$} & \multicolumn{8}{|c|}{ Kluczowe sektory według } \\
\hline & \multicolumn{2}{|c|}{$\begin{array}{l}\text { wartości nakładów } \\
\text { inwestycyjnych } \\
\text { (w mld USD) }\end{array}$} & \multicolumn{2}{|c|}{ liczby projektów } & \multicolumn{2}{|c|}{ liczby przedsiębiorstw } & \multicolumn{2}{|c|}{$\begin{array}{l}\text { liczby utworzonych } \\
\text { miejsc pracy }\end{array}$} \\
\hline & $\begin{array}{l}\text { Węgiel, ropa } \\
\text { i gaz }\end{array}$ & 176,4 & $\begin{array}{l}\text { Oprogram. } \\
\text { i usługi IT }\end{array}$ & 3444 & $\begin{array}{l}\text { Oprogram. } \\
\text { i usługi IT }\end{array}$ & 2253 & $\begin{array}{l}\text { Pośrednictwo } \\
\text { nieruchomości }\end{array}$ & 486147 \\
\hline 2. & $\begin{array}{l}\text { Pośrednictwo } \\
\text { nieruchomości }\end{array}$ & 168,3 & Usługi biznesowe & 2491 & Usługi biznesowe & 1651 & Tekstylia & 367125 \\
\hline 3. & $\begin{array}{l}\text { Alternatywne/ } \\
\text { odnawialne } \\
\text { źródła energii }\end{array}$ & 113,4 & Tekstylia & 2480 & $\begin{array}{l}\text { Maszyny przemy- } \\
\text { słowe, wyposaże- } \\
\text { nie i narzędzia }\end{array}$ & 1111 & $\begin{array}{l}\text { Produkty kon- } \\
\text { sumpcyjne }\end{array}$ & 293188 \\
\hline 4. & Komunikacja & 83,0 & $\begin{array}{c}\text { Usługi } \\
\text { finansowe }\end{array}$ & 1834 & $\begin{array}{c}\text { Usługi } \\
\text { finansowe }\end{array}$ & 950 & $\begin{array}{l}\text { Części samo- } \\
\text { chodowe }\end{array}$ & 255445 \\
\hline 5. & $\begin{array}{l}\text { Motoryzacja } \\
\text { (OEM) }\end{array}$ & 68,0 & $\begin{array}{l}\text { Maszyny przemy- } \\
\text { słowe, wyposaże- } \\
\text { nie i narzędzia }\end{array}$ & 1500 & Tekstylia & 807 & Żywność i tytoń & 245817 \\
\hline 6. & Metale & 62,8 & Komunikacja & 1358 & Komunikacja & 774 & $\begin{array}{l}\text { Oprogram. } \\
\text { i usługi IT }\end{array}$ & 225410 \\
\hline 7. & $\begin{array}{c}\text { Usługi } \\
\text { finansowe }\end{array}$ & 55,9 & $\begin{array}{l}\text { Produkty kon- } \\
\text { sumpcyjne }\end{array}$ & 1255 & Żywność i tytoń & 649 & $\begin{array}{l}\text { Motoryzacja } \\
\text { (OEM) }\end{array}$ & 216709 \\
\hline 8. & Chemikalia & 53,7 & Żywność i tytoń & 1201 & $\begin{array}{l}\text { Produkty kon- } \\
\text { sumpcyjne }\end{array}$ & 610 & $\begin{array}{l}\text { Usługi bizne- } \\
\text { sowe }\end{array}$ & 186901 \\
\hline 9. & Tekstylia & 47,4 & Transport & 1052 & $\begin{array}{c}\text { Części samocho- } \\
\text { dowe }\end{array}$ & 595 & $\begin{array}{l}\text { Części elektro- } \\
\text { niczne }\end{array}$ & 154082 \\
\hline 10. & Transport & 45,6 & $\begin{array}{c}\text { Części samocho- } \\
\text { dowe }\end{array}$ & 915 & Transport & 495 & Komunikacja & 150508 \\
\hline
\end{tabular}

Źródło: http://www.fdimarkets.com/ (20.04 2016).

Następujące w latach 1990-2014 zmiany strukturze branżowej BIZ, przesuwające strumienie tych inwestycji z przemysłu w kierunku usług, zwłaszcza finansowych, a przy tym możliwość dzielenia produkcji usług na poszczególne etapy i zadania (fragmentaryzacja produkcji) oraz wykonywanie ich w krajach o niższych kosztach (wynikających również z niższych stawek podatkowych) i związany z tą możliwością szybki rozwój działalności outsourcingowej i offshoringowej, wzrost w międzynarodowej wymianie handlowej nie tylko usług finalnych, ale też komponentów, wraz z pogłębiającą się złożonością współcześnie działających KTN - wszystko to łącznie stworzyło warunki do budowania przez korporacje transnarodowe struktur organizacyjnych wykorzystujących podmioty specjalnego przeznaczenia 


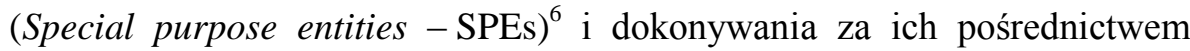
przepływów kapitałowych, które mają na celu optymalizację obciążeń podatkowych.

\section{PODATKI JAKO DETERMINANTA BIZ}

Podatki, a w szczególności podatki od dochodów przedsiębiorstw, stanowią jedną $\mathrm{z}$ wielu potencjalnych determinant BIZ. Wynika to $\mathrm{z}$ faktu, że wraz ze wzrostem opodatkowania zmniejsza się zyskowność inwestycji, a zatem bodźce do inwestowania ulegają osłabieniu (Wawrzyniak, 2013, s. 74). Z kolei niższe stawki podatkowe przyciągają inwestorów zagranicznych. Relacje pomiędzy podatkami i BIZ były przedmiotem wielu badań. Przykładowo J.R. Hines za pomocą analizy ekonometrycznej dowiódł, że obniżenie efektywnej stopy podatkowej (effective tax rate) średnio o $1 \%$ zwiększa napływ BIZ do kraju goszczącego o ok. 2\% (Hines, 1999, s. 309). Pomimo że niskie stawki podatkowe oraz zachęty fiskalne zachęcają do podejmowania inwestycji, to jednak badania przeprowadzone przez brytyjskiego specjalistę $\mathrm{w}$ dziedzinie bezpośrednich inwestycji zagranicznych J.H. Dunninga pokazują, że polityka podatkowa z uwzględnieniem ulg podatkowych nie znajduje się w grupie najważniejszych czynników decydujących o lokalizacji inwestycji bezpośrednich (Dunning, 2003, s. 11; 2004, s. 5; 2006, s. 206). Autor sporządził bogatą listę czynników lokalizacyjnych, którą podzielił na trzy zasadnicze grupy, a mianowicie: ramy kształtowania polityki dla BIZ (policy framework for FDI), czynniki ekonomiczne (eco-

\footnotetext{
${ }^{6}$ Podmioty specjalnego przeznaczenia są to działające zgodnie z prawem jednostki, formalnie zarejestrowane, które tworzone są zwykle w celu zabezpieczenia firmy przez ryzykiem finansowym. Są one powszechnie wykorzystywane do zmniejszania osiągniętych w ramach grupy kapitałowej zysków, ukrywania informacji o właścicielach oraz tworzenia nieprzejrzystych relacji między różnymi podmiotami, które w rzeczywistości są ze sobą powiązane. W szczególności wykorzystuje się je przy fuzjach i przejęciach. Uzyskiwane korzyści podatkowe mogą być związane z prawodawstwem występującym w danym kraju, ale często wynikają one również $\mathrm{z}$ dwustronnych umów o unikaniu podwójnego opodatkowania (The avoidance of double taxation - TADT). KTN za pośrednictwem spółek zakładanych w różnych jurysdykcjach mogą dokonać inwestycji w kraju macierzystym, uzyskując korzyści wynikające z TADT (NBP, 2014, s. 37). SPEs charakteryzują się zwykle tym, że są zakładane na terenie innego kraju niż przedsiębiorstwo macierzyste, zatrudniają one niewielu pracowników lub nie zatrudniają ich wcale i nie prowadzą też działalności operacyjnej w kraju, w którym zostały założone przez macierzyste przedsiębiorstwo. Ponadto są często traktowane jako narzędzie służące do pozyskiwania kapitału. Jako instrument prawny SPEs są względnie tanie zarówno pod względem utworzenia, jak i utrzymania. Dostarczają one korzyści podatkowych, regulacyjnych oraz w zakresie poufności. Funkcjonowanie SPEs jest często powiązane z działalnością offshoringowych centrów finansowych (OECD, 2008, s. 100-101; UNCTAD, 2015a, s. 3).
} 
nomic determinants) oraz ułatwienia dotyczące prowadzenia działalności gospodarczej (business facilitation). Podatki zostały umieszczone przez J.H. Dunninga w pierwszej z wymienionych grup. Natomiast korporacje transnarodowe podejmując decyzje opierają się głównie na czynnikach ekonomicznych odnoszących się do KTN poszukujących rynków, zasobów, efektywności i aktywów. Dla KTN poszukujących rynków (market-seeking) ważna jest wielkość rynku kraju goszczącego oraz możliwości jego rozwoju. Natomiast KTN poszukujące zasobów (resource-seeking) biorą pod uwagę koszty surowców oraz siły roboczej. Dla korporacji transnarodowych ukierunkowanych na efektywność (efficiency-seeking) cenna jest z kolei wydajność dostępnych zasobów oraz udział kraju w regionalnych porozumieniach integracyjnych, sprzyjający promowaniu bardziej efektywnego pod względem kosztowym podziału pracy pomiędzy krajami. I wreszcie, czynnikami kluczowymi dla KTN poszukujących strategicznych aktywów (asset-seeking) są technologiczne, menedżerskie, relacyjne i inne niematerialne aktywa, infrastruktura fizyczna, innowacyjność oraz poziom rozwoju instytucji na terenie kraju przyjmującego.

Należy zaznaczyć, że spośród wymienionych determinant ekonomicznych stawki podatkowe i zachęty fiskalne mają mniejsze znaczenie dla firm kierujących się przy wejściu na zagraniczne rynki motywem poszukiwania rynków lub poszukiwania zasobów. $\mathrm{W}$ takim przypadku decyzja o podjęciu inwestycji w danej lokalizacji związana jest zazwyczaj z wielkością i możliwościami rozwoju rynku lub dostępnością występujących na danym terytorium zasobów. Niskie stawki i zachęty podatkowe zyskują natomiast na znaczeniu w sytuacji, gdy korporacje transnarodowe poszukują efektywności, szczególnie $\mathrm{w}$ działalności przemysłowej zorientowanej na eksport. Tego rodzaju inwestycje nie są bowiem niczym skrępowane (footloose), nie są też związane z konkretną lokalizacją i są podejmowane tam, gdzie koszty działalności są niższe. A zatem dążenie do minimalizacji kosztów związanych z prowadzeniem działalności gospodarczej sprawia, że zachęty podatkowe stają się ważną częścią inwestycyjnych decyzji podejmowanych przez KTN (Kransdorff, 2010, s. 71). Inwestorzy zagraniczni poszukujący efektywności chętnie podejmują inwestycje w specjalnych strefach ekonomicznych lub na innych obszarach podatkowo uprzywilejowanych. Bez specjalnych zachęt podatkowych lub oferowanych niskich (bądź zerowych) stawek podatkowych niektóre lokalizacje byłyby nieatrakcyjne dla inwestorów zagranicznych.

Ponadto w literaturze przedmiotu zwraca się uwagę na znaczenie ogólnych warunków dla inwestycji występujących w kraju goszczącym, takich jak: ekonomiczna, polityczna i społeczna stabilizacja kraju, jakość klimatu 
do prowadzenia działalności gospodarczej, standardy dotyczące traktowania firm zagranicznych, jakość regulacji prawnych oraz poziom przestrzegania prawa, restrykcje w zakresie handlu, poziom ochrony własności intelektualnej itp. Przykładowo O.C. Popovici i A.C. Călin podkreślają, że podatki i związane z nimi zachęty są ważne dla inwestorów zagranicznych, ale dopiero po bardziej fundamentalnych kwestiach, takich jak ład instytucjonalny czy dobrze rozwinięta infrastruktura publiczna (Popovici, Călin, 2012, s. 62).

Pomimo że podatki w teoriach ekonomicznych dotyczących BIZ nie są uznawane za ważną determinantę lokalizacyjną, to jednak praktyka pokazuje, że kwestie związane $\mathrm{z}$ podatkami zaczynają odgrywać coraz większą rolę w decyzjach lokalizacyjnych KTN. Niejednokrotnie wybór obszaru uprzywilejowanego pod względem podatkowym stanowi pierwszy krok KTN w operacjach podejmowanych $\mathrm{w}$ ramach globalnego łańcucha wartości (global value chains).

Korporacje transnarodowe, działające $\mathrm{w}$ interesie swoich akcjonariuszy w legalny sposób starają się zmniejszyć obciążenia podatkowe związane $\mathrm{z}$ inwestycjami zagranicznymi i osiąganym $\mathrm{w}$ wyniku tych inwestycji zyskiem. Poprzez swoją strukturę organizacyjną i wykorzystywanie SPEs dokonują geograficznej dywersyfikacji inwestycji podejmowanych w postaci BIZ. Dywersyfikacja ta jest szczególnie widoczna w przypadku BIZ odpływających (outward foreign direct investment - OFDI) z Chin. Chińskie firmy dążąc do osiągnięcia korzyści podatkowych dokonują początkowych inwestycji w rajach podatkowych (tax havens) lub finansowych centrach offshoringowych, gdzie są minimalne podatki lub nie ma ich wcale, takich jak Hongkong czy Kajmany. Następnie te same środki finansowe przepływają do innych lokalizacji, takich jak Afryka i Ameryka Łacińska przez podmioty zależne, funkcjonujące $\mathrm{w}$ postaci finansowych centrów offshoringowych. Nie jest to jednak widoczne w oficjalnych statystykach chińskich OFDI, bowiem uwzględniają one jedynie początkową lokalizację inwestycji. W literaturze przedmiotu podkreśla się, że wiele fuzji i przejęć dokonywanych przez chińskie przedsiębiorstwa odbywa się za pomocą środków finansowych przepływających początkowo do Hongkongu (China's Overseas..., 2016). Przykładowo w 2011 r. największa rafineria ropy naftowej w Chinach Sinopec nabyła 30\% udziałów w brazylijskim koncernie Galp Energia za kwotę 5,2 mld USD poprzez swoją spółkę zależną International Petroleum Exploration and Development Corporation (SIPC) zlokalizowaną w Hongkongu. Z analiz przeprowadzonych przez R. Morocka, B. Yeunga i M. Zhao dotyczących chińskich BIZ wynikało, że $44,4 \%$ oficjalnego strumienia OFDI tego kraju w 2006 r. stanowiły inwestycje bezpośrednio związane 
z Kajmanami, a 39,3\% z Hongkongiem (Morock, Yeung, Zhao, 2008, s. 340). A obecnie szacuje się, że na Hongkong, Kajmany i Brytyjskie Wyspy Dziewicze przypada ok. 70\% chińskiego zasobu OFDI (Garcia-Herrero, Xia, Casanova, 2015, s. 3). Inwestowanie w rajach podatkowych widoczne jest także, gdy się spojrzy na napływające BIZ (inward foreign direct investment - IFDI) do chińskiej gospodarki. W przypadku napływu BIZ do Chin zwraca się uwagę na zjawisko round tripping. Polega ono na eksporcie kapitału z chińskiej gospodarki do SPEs w rajach podatkowych, a następnie jego powrocie $\mathrm{w}$ postaci BIZ i czerpaniu korzyści wynikających $\mathrm{z}$ różnego traktowania inwestorów krajowych i zagranicznych (Sutherland, Matthews, 2009, s. 2 i 6). Szacuje się, że zjawisko to stanowi ok. 40\% napływających do Chin IFDI (Garcia-Herrero, Xia, Casanova, 2015, s. 5).

$\mathrm{Na}$ rosnące znaczenie kwestii podatkowych $\mathrm{w}$ decyzjach lokalizacyjnych KTN podejmujących BIZ wskazuje także struktura polskich inwestycji bezpośrednich. W latach 2011-2012 aż 60\% polskich BIZ stanowiły inwestycje dokonywane przez polskie podmioty kontrolowane przez podmioty zagraniczne dominujące $\mathrm{w}$ grupach kapitałowych. Podmioty te inwestowały za pośrednictwem jednostek specjalnego przeznaczenia m.in. w takich krajach jak: Niderlandy, Cypr, Wielka Brytania, Szwajcaria czy Luksemburg. Kierowany do SPEs kapitał związany był przede wszystkim z usługami (finanse, działalność profesjonalna i administrowanie). Ulokowany w SPEs kapitał był następnie transferowany do kraju docelowego inwestycji, gdzie rodzaj prowadzonej działalności gospodarczej był zazwyczaj inny (NBP, 2014, s. 28-30). Patrząc na strukturę zarówno geograficzną, jak i branżową polskich OFDI można stwierdzić, że większość z nich była dokonywana w celu optymalizacji obciążeń podatkowych $\mathrm{w}$ ramach międzynarodowych grup kapitałowych.

Szacuje się, że Polska z tytułu unikania opodatkowania przez zagraniczne firmy traci rocznie ok. 46 mld USD (Raś, 2016).

Należy zaznaczyć, że z problemami dotyczącymi ucieczek KTN do innych państw w celu płacenia niższych podatków borykają się nie tylko kraje mniej rozwinięte, ale również te charakteryzujące się wysokim poziomem rozwoju. Okazuje się, że w Stanach Zjednoczonych ministerstwo finansów już trzykrotnie zaostrzało regulacje dotyczące inwersji podatkowej (tax inversion). Ostatnie zmiany wprowadzone w 2016 r. uniemożliwiają przeprowadzenie fuzji z zagranicznymi firmami, które są zbyt małe, aby być partnerem amerykańskich KTN. Ponadto zgodnie z nowymi przepisami do obliczania wielkości zagranicznej firmy nie będzie można brać pod uwagę transakcji z trzech lat poprzedzających fuzję. A to oznacza, że firmy amerykańskie będą zmuszone do dokonywania fuzji z takimi partnerami, których 
wielkość odpowiada przynajmniej jednej czwartej firmy amerykańskiej. Wcześniej amerykańskie KTN łączyły się z niewielkimi firmami zagranicznymi, aby za granicą płacić niższe podatki, pomimo że większość z nich swoją działalność biznesową nadal prowadziła na terenie USA (USA: Pfizer rezygnuje $z$ fuzji..., 2016). Zaostrzone przepisy w zakresie inwersji podatkowej w USA zapobiegły m.in. przejęciu przez amerykańską firmę Pfizer Inc. - giganta w branży farmaceutycznej, którego wartość rynkowa szacowana jest na 200 mld USD, relatywnie mniejszej irlandzkiej firmy Allergan PLC (Pfizer Walks Away..., 2016).

Jak duża jest skala problemu związanego z unikaniem opodatkowania pokazują analizy brytyjskiej organizacji Tax Justice Network monitorującej to zjawisko. Wynika z nich, że do ponad 80 ukrytych (secrecy) jurysdykcji w postaci rajów podatkowych i centrów offshoringowych na świecie przepłynął w latach 2010-2012 wirtualny kapitał o wartości pomiędzy 21 a 32 biliony dolarów (Henry, 2012, s. 5).

Ch. Jones i Y. Temouri (Jones, Temouri, 2016) poszukując z kolei odpowiedzi na pytanie, jakie czynniki decydują o lokowaniu BIZ w rajach podatkowych, stwierdzili na podstawie badań przeprowadzonych $\mathrm{w}$ ponad 14 tys. KTN z dwunastu krajów OECD, że czynnikami sprzyjającymi są przede wszystkim określone modele kapitalizmu występujące w kraju macierzystym KTN oraz poziom technologicznego zaawansowania tych podmiotów. Według autorów, KTN chętniej inwestują za pomocą podmiotów zależnych $\mathrm{w}$ rajach podatkowych, gdy prowadzą działalność produkcyjną lub usługową $\mathrm{w}$ branżach technologicznie intensywnych, które charakteryzują się dużym poziomem i wartością niematerialnych aktywów. Ponadto autorzy wykazali, że znacznie więcej KTN podejmuje inwestycje na obszarach podatkowo uprzywilejowanych, gdy firma macierzysta pochodzi z kraju, w którym występuje gospodarka liberalna (liberal market economies LMEs) w porównaniu z gospodarkami rynkowymi opartymi na koordynacji (coordinated market economies-CMEs) ${ }^{7}$. Autorzy dowiedli również, że niewielki wpływ na decyzje $\mathrm{w}$ zakresie optymalizacji podatkowej mają stawki podatku od dochodów przedsiębiorstw w kraju macierzystym KTN, co sugeruje, że jest mało prawdopodobne, aby przeprowadzana w nich libe-

\footnotetext{
${ }^{7}$ W przypadku KTN pochodzących z LMEs, najwięcej KTN inwestowało w rajach podatkowych z USA (56,56\%), Australii (51,95\%) oraz Nowej Zelandii (29,41\%). Biorąc z kolei pod uwagę KTN pochodzące z CMEs udziały te były znacznie niższe. W przypadku Danii wynosiły $20,13 \%$, Japonii $19,83 \%$ i Szwecji $17,65 \%$. Najmniej w rajach podatkowych inwestowały korporacje niemieckie, austriackie i fińskie. Udziały tego typu przedsiębiorstw w ogólnej liczbie KTN w poszczególnych krajach wynosił odpowiednio: 9,60\%, 8,27\% i 6,88\% (Jones, Temouri, 2016, s. 242).
} 
ralizacja i obniżanie stawek podatkowych mogły skutecznie zniechęcać i odwodzić KTN od podatkowych ucieczek (Jones, Temouri, 2016, s. 237).

\section{MECHANIZMY UNIKANIA PODATKÓW}

W literaturze przedmiotu zwraca się uwagę, że zjawisko dotyczące unikania płacenia podatków oraz przesuwania dochodów do lokalizacji krajów o niższym opodatkowaniu lub braku opodatkowania (BEPS) ma charakter globalny, odnosi się ono bowiem do wszystkich krajów na świecie. Podkreśla się, że mechanizm polegający na inwestowaniu w centrach offshoringowych jest zasadniczo podobny dla krajów rozwiniętych i rozwijających się, jednakże skutki przesuwania dochodów z krajów mniej rozwiniętych mogą mieć dla nich dużo większy negatywny wpływ w porównaniu z krajami rozwiniętymi. Kraje znajdujące się na niższym poziomie rozwoju są bowiem w mniejszym stopniu przygotowane do radzenia sobie $\mathrm{z}$ bardzo skomplikowanymi praktykami w zakresie unikania podatków, ze względu brak określonej wiedzy i ekspertów w tej dziedzinie. Szacuje się, że kraje rozwijające się tracą ok. 100 mld USD rocznych wpływów do budżetu z tytułu inwestycji bezpośrednio powiązanych $\mathrm{z}$ centrami offshoringowymi (UNCTAD, 2015a, s. xiii). Analizy przeprowadzone przez UNCTAD wskazują, że istnieje zależność pomiędzy udziałem inwestycji w centrach offshoringowych $\mathrm{w}$ całościowych zasobach BIZ napływających do kraju goszczącego a stopą zwrotu $\mathrm{z}$ tych inwestycji. Przyjmuje się, że dla krajów rozwijających się każde 10 punktów procentowych inwestycji związanych z centrami offshoringowymi przyczynia się do spadku stopy zwrotu z tych inwestycji przeciętnie o 1 punkt procentowy (UNCTAD, 2015a, s. 200).

O tym jak istotną rolę odgrywają centra offshoringowe w globalnych inwestycjach, świadczy fakt, że ok. 30\% ponadnarodowych zasobów inwestycji dokonanych przez KTN przepłynęło przez kraje tranzytowe zanim osiągnęły one docelową lokalizację dla produkcyjnych aktywów. Przykładowo w 2012 r. Brytyjskie Wyspy Dziewicze (BWD) były piątym największym odbiorcą BIZ na świecie $\mathrm{z}$ wartością strumienia napływu na poziomie 65 mld USD, wyższym od Wielkiej Brytanii, do której napłynęło w tymże roku 62 mld USD (UNCTAD, 2013, s. 3), a której gospodarka ma 1600 razy większą powierzchnię i liczy prawie 2800 razy więcej mieszkańców od BWD. Podobnie kształtowała się sytuacja w zakresie odpływu BIZ. Wartość 42 mld USD, która odpłynęła z BWD jest niewspółmierna do wielkości gospodarki tego kraju. Offshoringowe centra inwestycyjne (offshore investment hubs) mogą przyjmować postać jurysdykcji identyfikowanych jako raje podatkowe lub jurysdykcji, nie będących rajami podatkowymi, oferujących 
SPEs lub inne podmioty ułatwiające przepływ inwestycji. Raje podatkowe to niewielkie jurysdykcje, których gospodarka jest w całości lub prawie całkowicie przeznaczona do świadczenia usług finansowych. Według OECD (OECD, 1998, s. 23-24) rajem podatkowym jest obszar, który charakteryzuje się takim cechami, jak: 1) brak podatku dochodowego lub podatek dochodowy o czysto nominalnym charakterze, 2) brak efektywnej wymiany informacji ( $w$ rajach podatkowych firmy i osoby prywatne mogą w obrębie istniejących przepisów lub praktyk administracyjnych korzystać ze ścisłych zasad poufności i innych zabezpieczeń chroniących ich prze kontrolą ze strony organów podatkowych), 3) brak przejrzystości w zakresie funkcjonowania przepisów ustawodawczych, prawnych i administracyjnych, 4) brak wymogu wskazania, co stanowi zasadniczy rodzaj działalności określonych podmiotów. W $2000 \mathrm{r}$. OECD stworzyło listę rajów podatkowych na świecie zaliczając do niej 38 państw, jednakże wraz z upływem czasu lista krajów spełniających kryteria OECD zwiększyła się do 50 (tabela 4).

Tabela 4. Wykaz rajów podatkowych na świecie spełniających kryteria definicyjne OECD

\begin{tabular}{|c|c|}
\hline Region & Kraje \\
\hline $\begin{array}{c}\text { Karaiby } \\
\text { (wcześniej Indie Zachodnie) }\end{array}$ & $\begin{array}{l}\text { Anguilla, Antigua i Barbuda, Aruba, Bahamy, Barbados, Bry- } \\
\text { tyjskie Wyspy Dziewicze, Kajmany, Dominika, Grenada, } \\
\text { Montserrat, Antyle Holenderskie, Saint Kitts i Nevis, Saint } \\
\text { Lucia, Saint Vincent i Grenadyny, Wyspy Turks i Caicos, Wy- } \\
\text { spy Dziewicze Stanów Zjednoczonych }\end{array}$ \\
\hline Ameryka Środkowa & Belize, Kostaryka, Panama \\
\hline Azja Wschodnia & Hongkong, Makau, Singapur \\
\hline $\begin{array}{c}\text { Europa } \\
\text { (region Morza Śródziemnego) }\end{array}$ & $\begin{array}{c}\text { Andora, Wyspy Normandzkie (Guemsey i Jersey), Cypr, Gi- } \\
\text { braltar, Wyspa Man, Irlandia, Liechtenstein, Luksemburg, } \\
\text { Malta, Monako, San Marino, Szwajcaria }\end{array}$ \\
\hline Region Oceanu Indyjskiego & Malediwy, Mauritius, Seszele \\
\hline Bliski Wschód & Bahrajn, Jordania, Liban \\
\hline Region Północnoatlantycki & Bermudy \\
\hline $\begin{array}{c}\text { Region Pacyfiku } \\
\text { i Południowego Pacyfiku }\end{array}$ & $\begin{array}{c}\text { Wyspy Cooka, Wyspy Marshalla, Samoa, Nauru, Niue, } \\
\text { Tonga, Vanuatu }\end{array}$ \\
\hline Afryka Zachodnia & Liberia \\
\hline
\end{tabular}

Źródło: (Gravelle, 2015, s. 4).

W odróżnieniu od rajów podatkowych, jurysdykcje oferujące SPEs lub inne podmioty ułatwiające przepływ inwestycji są na ogół większe. Charakteryzują się tym, że na ich terytorium może być prowadzona rzeczywista, a nie tylko na zasadzie skrzynki pocztowej (letterbox) działalność gospodarcza, choć często i one mają miejsce. Jurysdykcje te działają zwykle jako główne globalne centra inwestycyjne KTN ze względu na korzystne warunki 
podatkowe i inwestycyjne. Z uwagi na brak precyzyjnego określenia oraz podejścia do kryteriów klasyfikacji inwestycji offsohoringowych i działalności w centrach inwestycyjnych trudniej jest w tym przypadku o precyzyjne lokalizacje oraz statystyki. Jakkolwiek szacuje się, że ok. 19\% BIZ na świecie przechodzi przez SPEs, a spośród regionów odsetek ten jest najwyższy w Europie i wynosi 32\% (UNCTAD, 2015, s. 199). W SPEs specjalizują się szczególnie dwa europejskie kraje, a mianowicie Holandia i Luksemburg. $\mathrm{Z}$ danych za 2010 rok wynika, że na terytorium Holandii za pośrednictwem 14300 podmiotów specjalnego przeznaczenia zostało przetransferowanych 10,2 biliona euro (Przez holenderskie..., 2013). W przypadku Luksemburga statystyki pokazują z kolei, że aż 93\% zasobów napływu BIZ do tego kraju i 90\% zasobów odpływu tych inwestycji w 2011 r. było powiązanych z działalnością SPEs (UNCTAD, 2012, s. 7).

Korporacje transnarodowe dysponują dużą liczbą mechanizmów, które umożliwiają im unikanie płacenia podatków. UNCTAD wyróżnił w tym względzie trzy główne czynniki kreujące oraz dziesięć szczegółowych (tabela 5).

Tabela 5. Główne mechanizmy w zakresie unikania podatków według UNCTAD

\begin{tabular}{|c|c|}
\hline $\begin{array}{l}\text { Czynniki kreujące } \\
\text { (enabling factor) }\end{array}$ & $\begin{array}{c}\text { Mechanizmy szczegółowe } \\
\text { (specific levers) }\end{array}$ \\
\hline Zróżnicowane stawki podatkowe & $\begin{array}{l}\text { - możliwości manipulowania przy stosowaniu cen transfe- } \\
\text { rowych (nieprawidłowa wycena towarów będących } \\
\text { przedmiotem wymiany handlowej, wykorzystywanie ak- } \\
\text { tywów niematerialnych i własności intelektualnej itp.) } \\
\text { - nadmierne finansowanie długu } \\
\text { - inne (np. planowanie konkretnej lokalizacji ze względów } \\
\text { podatkowych, wykorzystywanie straty) }\end{array}$ \\
\hline $\begin{array}{c}\text { Dysharmonia przepisów i/lub luki } \\
\text { prawne }\end{array}$ & $\begin{array}{l}\text { - porozumienia hybrydowe } \\
\text { - transakcje pochodne } \\
\text { - ukrywanie krajowych inwestycji } \\
\end{array}$ \\
\hline $\begin{array}{l}\text { Kwestie zwiazane z podwójnym opo- } \\
\text { datkowaniem }\end{array}$ & $\begin{array}{l}\text { - nabywanie korzyści umownych (treaty shopping) } \\
\text { - transakcje trójstronne } \\
\text { - omijanie progów zawartych w umowach }\end{array}$ \\
\hline
\end{tabular}

Występujące pomiędzy krajami różnice w zakresie stawek podatkowych, niedoskonałość przepisów prawa podatkowego, szczególnie zaś w zakresie umów dotyczących podwójnego opodatkowania rodzi wśród KTN pokusę 
nadużyć ${ }^{8}$. Afery podatkowe związane $\mathrm{z}$ takimi firmami, jak: Wall-mart, Starbucks, Yahoo, Dell, Google, Apple, Facebook czy Amazon skrzętnie odnotowywane $\mathrm{w}$ doniesieniach prasowych pokazują, że firmy te na dużą skalę stosują optymalizację podatkową („Independent”, 2016; „The Guardian” 2016). Przykładowo z analiz Bloomberga wynika, że firma Apple dzięki inwestycjom w Irlandii zapłaciła zaledwie $1,8 \%$ podatku, podczas gdy dochody osiągnięte przez tę firmę stanowiły ok. 55\% jej całkowitych przychodów uzyskanych poza granicami USA (Gilbert, 2016).

\section{SPOSOBY PRZECIWDZIAŁANIA BEPS}

Unikanie płacenia podatków przez korporacje transnarodowe, które osiągają wielomiliardowe zyski (w pierwszym kwartale 2016 r. firma Apple odnotowała najwyższy w historii swojej działalności zysk kwartalny netto na poziomie 18,4 mld USD), pomimo że działają one w granicach obowiązującego prawa, postrzegane jest jako zjawisko nieuczciwe oraz szkodliwe pod względem społecznym i ekonomicznym. Z badań przeprowadzonych w 2015 r. przez organizację Christian Aid na terenie jednego z europejskich rajów podatkowych, a mianowicie Irlandii wynikło, że aż 70\% badanych pełnoletnich mieszkańców tego kraju unikanie podatków przez firmy międzynarodowe (nawet jeśli działalność ta była legalna) uznało za moralnie naganne (Christian Aid, 2015). Coraz częściej pojawiają się także opinie, że praktyki związane z unikaniem przez KTN płacenia podatków naruszają poczucie sprawiedliwości ${ }^{9}$ oraz $\mathrm{w}$ istotny sposób zakłócają występującą na rynku konkurencję, oraz że w sposób skuteczny należy przeciwdziałać zaistniałej sytuacji (Eurodad, 2015, s. 8). Pierwszy znaczący krok w tym względzie, mający na celu ograniczenie unikania przez KTN płacenia podatków oraz przesuwania przez nie dochodów do lokalizacji krajów o niższym opodatkowaniu lub braku opodatkowania (BEPS) poczyniła w 2013 r. OECD, opracowując 15-punktowy Plan Działań, zmierzający do stworzenia jednolitych, międzynarodowych zasad podatkowych (tabela 6).

Zaproponowany przez OECD projekt mający na celu przeciwdziałanie BEPS opierał się na trzech głównych filarach, a mianowicie: 1) wprowadzeniu spójności $\mathrm{w}$ przepisach krajowych dotyczących działalności transgra-

\footnotetext{
${ }^{8}$ Szerzej na ten temat pisze m.in. S. Bryndziak w artykule pt. „Nadużywanie przepisów umów o unikaniu podwójnego opodatkowania przez transfer rezydencji podatkowej” (Bryndziak, 2014, s. 37-44).

${ }^{9} \mathrm{Z}$ badań przeprowadzonych przez I. Ortiz i in. wynika, że spośród 488 protestów zorganizowanych na świecie w latach 2006-2013, które były związane ze sprawiedliwością ekonomiczną i oszczędnościami (Economic Justice and Austerity), 133 były motywowane sprawiedliwością podatkową (Ortiz i in, 2013, s. 15).
} 
nicznej, 2) wzmocnieniu wymogów prawnych dotyczących transakcji w istniejących standardach międzynarodowych $\mathrm{w}$ celu dostosowania miejsca opodatkowania do lokalizacji, w której faktycznie prowadzona jest działalność gospodarcza oraz tworzona jest wartość dodana oraz 3) poprawie przejrzystości i przewidywalności dla podmiotów gospodarczych.

Tabela 6. Wykaz 15 działań zaproponowanych przez OECD mających na celu ograniczenie zjawiska BEPS

\begin{tabular}{|c|c|}
\hline $\begin{array}{l}\text { Numer } \\
\text { działania }\end{array}$ & Działanie \\
\hline 1. & $\begin{array}{l}\text { Wyzwania podatkowe w gospodarce cyfrowej (uszczelnienie opodatkowania w zakresie } \\
\text { handlu elektronicznego) }\end{array}$ \\
\hline 2. & Neutralizowanie skutków wykorzystywania instrumentów hybrydowych \\
\hline 3. & $\begin{array}{l}\text { Wzmocnienie przepisów dotyczących kontrolowanych spółek zagranicznych (controlled } \\
\text { foreign company - CFC) }\end{array}$ \\
\hline 4. & $\begin{array}{l}\text { Ograniczenie erozji podstawy opodatkowania przez odliczenia odsetek i innych finanso- } \\
\text { wych płatności }\end{array}$ \\
\hline 5. & $\begin{array}{l}\text { Bardziej efektywne zwalczanie szkodliwych praktyk podatkowych i działanie w kierunku } \\
\text { zwiększenia przejrzystości }\end{array}$ \\
\hline 6. & Ograniczanie naruszania postanowień umów podatkowych (traty abuse) \\
\hline 7. & Przeciwdziałanie sztucznemu unikaniu statusu „zakładu” (permanent establishment) \\
\hline 8. & $\begin{array}{l}\text { Dażenie do tego, aby rezultaty stosowania cen transferowych dotyczących aktywów } \\
\text { niematerialnych były zgodne z tworzeniem wartości }\end{array}$ \\
\hline 9. & $\begin{array}{l}\text { Zapewnienie, aby rezultaty stosowania cen transferowych dotyczących ryzyka i kapitału } \\
\text { były zgodne z tworzeniem wartości }\end{array}$ \\
\hline 10. & $\begin{array}{l}\text { Zagwarantowanie, aby rezultaty stosowania cen transferowych dotyczące innych trans- } \\
\text { akcji o wysokim poziomie ryzyka były zgodne z tworzeniem wartości }\end{array}$ \\
\hline 11. & $\begin{array}{l}\text { Stworzenie odpowiedniej metodologii w zakresie zbierania i analizy danych dotyczących } \\
\text { BEPS, prowadzących do rozwiązania tego problemu }\end{array}$ \\
\hline 12. & $\begin{array}{l}\text { Wymaganie od podatników ujawniania stosowanych przez nich agresywnych strategii } \\
\text { podatkowych }\end{array}$ \\
\hline 13. & Ponowne zbadanie dokumentacji dotyczącej cen transferowych \\
\hline 14. & Poprawa efektywności mechanizmów rozwiązywania sporów \\
\hline 15. & $\begin{array}{l}\text { Stworzenie wielostronnego instrumentu umożliwiajacego wprowadzenie działań planu } \\
\text { BEPS oraz modyfikacji istniejacych umów o unikaniu podwójnego opodatkowania }\end{array}$ \\
\hline
\end{tabular}

Źródło: (OECD, 2013b, s. 14-25).

W latach 2013-2015 projekt opracowany przez OECD podlegał szerokim konsultacjom (pod koniec 2014 r. włączono do nich większą liczbę państw rozwijających się) i w ostatecznym kształcie został on opublikowany 5 października $2015 \mathrm{r}$. W finalnych raportach wprowadzono wiele nowych standardów. Do kluczowych należała m.in. konieczność raportowania „kraj po kraju" (contry-by country reporting), umożliwiająca administracji podatkowej analizę działalności przedsiębiorstw w skali globalnej. Ponadto wprowadzono zasady mające na celu zapobieganie nadużyciom w wykorzy- 
stywaniu udogodnień traktatowych (anti-treaty shoping) oraz ograniczenie szkodliwych praktyk podatkowych, szczególnie w obszarze własności intelektualnej. Do planu działań włączono także procedurę wzajemnego porozumiewania się (mutual agreements procedures), aby walka z BEPS nie prowadziła do podwójnego opodatkowania podmiotów. W nowym projekcie poświęcono także większą uwagę cenom transferowym. Dążono do tego, aby ceny te były w większym stopniu powiązane z tworzeniem wartości.

Działania zawarte w finalnych raportach OECD mają przede wszystkim na celu identyfikację i ograniczanie agresywnego planowania podatkowego i nieefektywnych praktyk administracyjnych, bowiem zgodnie z szacunkami OECD roczna strata wynikająca $\mathrm{z}$ transferu dochodów za granicę stanowi od $4 \%$ do $10 \%$ globalnych wpływów z podatków od przedsiębiorstw CIT, kwotowo oznacza to ubytek od 100 do 240 mld USD (OECD, 2015, s. 15).

Należy zaznaczyć, że OECD w walce z BEPS nie jest osamotniona, bowiem od samego początku oprócz wsparcia państw grupy G20, także Unia Europejska dążyła do współpracy, koordynacji działań, a tam gdzie to możliwe, także harmonizacji wdrożenia tego projektu. W komunikacie Komisji Europejskiej z 17 czerwca 2015 r. stwierdzono, że Unia Europejska powinna skorzystać z międzynarodowych reform zaproponowanych przez OECD i powinna rozważyć jak najlepsze zintegrowanie wyników projektu BEPS na szczeblu Wspólnoty (COM, 2015, s. 7). Oprócz tego Komisja przedstawiła własny plan działania w zakresie sprawiedliwego i skutecznego systemu opodatkowania przedsiębiorstw w UE składający się z pięciu głównych obszarów (COM, 2015, s. 8-17):

1. kompleksowe rozwiązanie w kwestii przenoszenia zysków (wdrożenie wspólnej kompleksowej podstawy opodatkowania osób prawnych),

2. zapewnienie efektywnego podatkowania w miejscu tworzenia zysków (zbliżenie opodatkowania zysków do miejsca ich generowania, poprawa ram prawnych dotyczących cen transferowych, poprawa systemów preferencyjnych z miejscem wytwarzania wartości ekonomicznej),

3. dodatkowe środki na rzecz lepszego otoczenia podatkowego dla przedsiębiorstw (umożliwienie transgranicznej kompensacji strat, usprawnienie mechanizmów rozwiązywania sporów dotyczących podwójnego opodatkowania),

4. dalsze postępy w obszarze przejrzystości podatkowej (zapewnienie bardziej jednolitego podejścia do jurysdykcji niechętnych do współpracy w kwestiach podatkowych w państwach trzecich, dalsze prace w zakresie przejrzystości opodatkowania przedsiębiorstw, w tym opcje sprawozdawczości w podziale na poszczególne kraje), 
5. narzędzia UE służące koordynacji (poprawa koordynacji działań państw członkowskich w zakresie audytów podatkowych, reforma postępowania w zakresie opodatkowania działalności gospodarczej oraz platformy ds. dobrego zarządzania w kwestiach podatkowych).

Zdaniem Komisji Europejskiej wdrożenie reform opracowanych przez OECD, jak też tych zaproponowanych na szczeblu unijnym powinno przyczynić się do stworzenia bardziej sprawiedliwego i efektywnego systemu w zakresie opodatkowania przedsiębiorstw.

\section{PODSUMOWANIE}

Unikanie płacenia podatków przez korporacje transnarodowe staje się obecnie jednym z poważniejszych problemów funkcjonowania gospodarki w skali globalnej. Z jednej strony rządy wielu krajów, szczególnie tych najdotkliwiej dotkniętych skutkami ostatniego kryzysu finansowo-gospodarczego, dążą do ograniczania wydatków budżetowych, z drugiej zaś korporacje transnarodowe inwestując $\mathrm{w}$ wielu krajach za pośrednictwem rajów podatkowych i SPEs pozbawiają je należnych wpływów z podatków. Konsekwencją stosowania przez KTN optymalizacji podatkowej jest także negatywne oddziaływanie na warunki konkurencji w poszczególnych krajach. Małe i średnie firmy rodzime nie stosują zwykle agresywnych strategii podatkowych, co osłabia ich zdolność do konkurowania z KTN, ze względu na wyższe koszty prowadzenia działalności gospodarczej. Ponadto kraje chcąc przyciągnąc BIZ na swoje terytorium prowadzą często swoistą „,walkę" na podatki, prześcigając się propozycjach dotyczących coraz korzystniejszych stawek oraz stosowanych bodźców (Wojna na podatki..., 2008). Niejednokrotnie korporacje transnarodowe wykorzystują też sytuację i same dyktują warunki, dążąc do jak najmniejszych obciążeń podatkowych. Taka sytuacja miała miejsce m.in. w Polsce, kiedy to nie inwestorzy zagraniczni podążali za specjalnymi strefami ekonomicznymi, a odwrotnie, to strefy podążały za inwestorami. Inwestorzy zagraniczni wskazywali najbardziej atrakcyjne dla siebie lokalizacje, a następnie udzielana była im pomoc publiczna w postaci zwolnień i ulg podatkowych (Pilarska, 2008, s. 66).

Podejmowanie inwestycji za pośrednictwem SPEs zniekształca także informacje dotyczące BIZ. W wielu przypadkach inwestycje bezpośrednie są związane z przepływami kapitału w tranzycie. A ten rodzaj BIZ w niewielkim stopniu oddziałuje na realne procesy zachodzące $\mathrm{w}$ gospodarce. $\mathrm{Z}$ punktu widzenia korzyści dla gospodarki kraju goszczącego najkorzystniejsze są inwestycje typu greenfield, którym wraz z przepływem środków finansowych towarzyszy także pakiet inwestycyjny w postaci przepływu czynników 
wytwórczych, w tym rzeczowych zasobów kapitałowych, wiedzy i technologii. Przepływający zaś kapitał do finansowych centrów offshoringowych albo dokonywanie fuzji i przejęć wyłącznie w celach podatkowych nie kreuje pozytywnych efektów zewnętrznych dla gospodarki kraju przyjmującego.

Do niekorzystnych zjawisk, które towarzyszą nasilającej się konkurencji podatkowej (uznanej przez OECD za szkodliwą), odbywającej się za pośrednictwem obszarów podatkowo uprzywilejowanych, można zaliczyć także oprócz zniekształcania informacji na temat rzeczywistych przepływów kapitału w postaci BIZ podważanie integralności i uczciwości struktur podatkowych, zniechęcanie innych podatników do płacenia podatków, trudności w kształtowaniu pożądanego poziomu oraz zestawu podatków, powodowanie niepożądanego przesunięcia części obciążeń podatkowych do mniej mobilnych podstaw opodatkowania, takich jak praca, nieruchomości czy konsumpcja oraz zwiększenie kosztów administracyjnych i obciążeń w zakresie egzekwowania przepisów podatkowych przez podatników (OECD, 1998, s. 16).

Problem optymalizacji podatkowej wymaga rozwiązania, jednakże aby to osiągnąc niezbędna jest wola polityczna i współdziałanie w tym zakresie wielu państw. Nie jest to jednak zadanie proste do realizacji bowiem praktyka pokazuje, że nie wszystkie państwa są tym zainteresowane. Nawet kraje należące do OECD i Unii Europejskiej, organizacji i ugrupowania, które jak przedstawiono powyżej zainicjowały walkę ze szkodliwą konkurencją podatkową, nie są w pełni zgodne co do zasadności podjętych działań. Część z nich uważa, że zaproponowane przez OECD rozwiązania naruszają ich suwerenność w zakresie stanowienia prawa podatkowego. Ponadto w wielu krajach zachęty podatkowe stanowią ważny instrument polityki mający na celu przyciągnięcie kapitału zagranicznego. Szczególnie istotny jest dla tych, które charakteryzują się strukturalnymi słabościami w postaci niekorzystnej geograficznej lokalizacji, braku zasobów naturalnych, wyspecjalizowanej siły roboczej czy dostatecznie rozwiniętej infrastruktury. Trzeba mieć także na uwadze fakt, że zmiany w zakresie reformowania i ujednolicania przepisów podatkowych w skali międzynarodowej naruszają interesy korporacji transnarodowych, a te dysponują ogromnymi środkami, które mogą być użyte na lobbing w zakresie utrzymania dotychczasowej konkurencji podatkowej. Nie ulega wątpliwości, że reformy systemów podatkowych na świecie w kierunku ich uszczelnienia są konieczne, jednak patrząc na złożoność materii, wydaje się że będzie to długotrwały proces. 


\section{LITERATURA}

Aggarwal R., Berrill J., Hutson E., Kearney C. (2011), What is multinational corporation? Classifying the degree of firm-level multinationality, „International Business Review”, 5, 557-577, DOI: 10.1016/j.busrev.2010.11.004.

Bryndziak S. (2014), Nadużywanie przepisów umów o unikaniu podwójnego opodatkowania przez transfer rezydencji podatkowej, Zeszyty Naukowe Uniwersytetu Szczecińskiego, $818,37-44$.

CASE (2003), Konsekwencje przystapienia Chin do WTO dla krajów sąsiednich, Warszawa, 69.

China's Overseas Investment, Explained in 10 Graphics, http://www.wri.org/ (19.04.2016).

Christian Aid (2015), Vast majority tax avoidance by maultinatipnals to be morally wrong, http://www.christianaid.ie/pressoffice/pressreleases/september_2015/Vast-majority-bel ieve-tax-avoidance-by-multinationals-to-be-morally-wrong.aspx (3.05. 2016).

COM (2015), Sprawiedliwy i skuteczny system opodatkowania przedsiębiorstw w Unii Europejskiej: pięć głównych obszarów działania, Komunikat Komisji do Parlamentu Europejskiego i Rady, Komisja Europejska, 302 final, Bruksela, 17 czerwca.

Dunning J.H. (2003), The Role of Foreign Direct Investment in Upgrading China's Competitiveness, „Journal of International Business and Economy”, 1, 1-13 .

Dunning J.H. (2004), Institutional Reform, FDI and European Transition Economies, Henley Business School University of Reading Whiteknights, United Kingdom, 014.

Dunning J.H. (2006), Towards a New Paradigm of Development: Implications for the Determinants International Business, „Transnational Corporations”, 1, 173-227.

Eurodad (2015), Fifty Shades of Tax Dodging. The EU's Role in supporting an unjust global tax system,http://www.eurodad.org/files/pdf/1546494-fifty-shades-of-tax-dodging-the-e u-s-role-in-supporting-an-unjust-global-tax-system.pdf (24.04.2016).

EY'attractiveness survey, Europe 2015, Comeback time, http://www.ey.com/Publication/vwL UAssets/EY-european-attractiveness-survey-2015/\$FILE/EY-european-attractivenesssurvey-2015.pdf (15.04.2016).

G20 Leaders'Declaration (2013), Adressing Base Erosion and Profit Shifting, Tackling Tax Avoidance, and Promoting Tax Transparency and Automatic Exchange of Information, G20 Summits, St Petersburg, 6 September, http://www.g20.utoronto.ca/2013/20130906-declaration.html (8.04.2016).

Garcia-Herrero A., Xia L., Casanova C. (2015), China's outbound foreign direct investment: How much goes where after round-tripping and offshoring?, BBVA, Working Paper, $15 / 17$.

Gilbert D. (2016), EU Probe of Apple's Tax Affairs in Ireland. Won't Conclude Any Time Soon, „International Business Times”, http://www.ibtimes.com/eu-probe-apples-taxaffairs-ireland-wont-conclude-any-time-soon-2331587 (2.05.2016).

Goś K. (2015), Efficiency considerations of matrix structures in multinational corporations, University of Warsaw, Warsaw, niepublikowana rozprawa doktorska.

Gottlieb M R. (2007), The Matrix Management Organization Reloaded, Adventures in Team and Project Management (Creating Corpotate Cultures), PRAEGER, London.

Gravelle J.G. (2015), Tax Havens: International Tax Avoidance and Evasion, Congressional Research Service 7-5700, https://www.fas.org/sgp/crs/misc/R40623.pdf (1.05.2016).

Henry J.S. (2012), The price of offshore revisited. New estimates for „,missing” global provate wealth, income, inequality, and taxes, Tax Justice Network, www.taxjustice.ne t/cms/upload/pdf/Price_of_Offshore_Revisited_120722.pdf (2.5.2016). 
Hines J.R., Lesson from Behavioral Responses to International Taxation, „National Tax Journal", 2, 305-322.

„Independent” (2016), Ernst \& Young: Accountancy giant advises Google, Apple, Facebook and Amazon on tax affairs, 27 January.

Jaworek M., Kuzel M. (2015), Transnational Corporations in the World Economy: Formation, Development and Present Position, Copernican Journal of Finance \& Accounting, 1, 55-70, DOI: http://dx.doi.org /10.12775/CJFA.2015.004.

Jones Ch., Temouri Y. (2016), The determinants of tax haven FDI, ,Journal of World Business, 2, 237-250, DOI: http://dx.doi.org.ebsco.han.uek.krakow.pl/10.1016/j.jwb.2015.09.001.

Kosztowniak A. (2015), Ekspansja korporacji transnarodowych w latach 1990-2013, „Gospodarka Narodowa”, 6, 101-128.

Kransdorff M., Tax Incentives and Foreign Direct Investment in South Africa, „The Journal of Sustainable Development" 2010, 1, 68-84.

NBP (2014), Polskie i zagraniczne inwestycje bezpośrednie w 2012 r., Warszawa.

OECD (1998), Harmful Tax Competition. An Emerging Global Issue, Paris.

OECD (2001), The New Economy: Beyond the Hype, Final Report on the OECD Growth Project, Paris, http://www.oecd.org/economy/growth/2380634.pdf (15.04.2016).

OECD (2013a), Adressing Base Erosion and Profit Shifting, Paris.

OECD (2013b), Action Plan on Base Erosion and Profit Shifting, Paris.

OECD (2015), Measuring and Monitoring BEPS. Action 11: 2015 Final Report, Paris.

Ortiz I., Burke S., Berrada M., Saenz H.C. (2013), World Protest 2006-2013, Initiative for Policy Dialogue and Fridriech-Ebert-Stiftung Working Paper, New York.

Pilarska C. (2008), Specjalne strefy ekonomiczne jako instrument polityki ekonomicznej państwa, [w:] Z. Dach (red.), Państwo a rynek we wspótczesnej gospodarce. Wybrane problemy, PTE, Kraków, 52-78 .

Pilarska C. (2013), Działalność podmiotów z kapitatem zagranicznym w Polsce $w$ warunkach wspótczesnego kryzysu gospodarczego, Zeszyty Naukowe Polskiego Towarzystwa Ekonomicznego, 14, 43-68.

Popovici O.C., Călin A.C. (2012), Attractiveness of Public Policies for FDI in Central and Eastern European Countries, Annals of the University of Oradea, Economic Science Series, 1, 61-67.

Przez holenderskie skrzynki pocztowe przeplywa 13 bilionów dolarów rocznie, http://www.pa rkiet.com/artykul/1303517.html (2.05.2016).

Raś L. (2016), Polska z tytułu unikania opodatkowania przez zagraniczne firmy traci rocznie ok. 46 mld zt, „Gazeta Prawna”, 6 kwietnia.

„Rzeczpospolita” (2008), Wojna na podatki o międzynarodowe inwestycje, 9 stycznia, http://www.rp.pl/artykul/82134-Wojna-na-podatki-o-miedzynarodowe-inwestycjesystem-iniowy-czechy-slowacja-.html\#ap-1 (26.04. 2016).

Sutherland D., Matthews B. (2009), Round Tripping or Capital Augmenting OFDI?, Chinese Outward Investment and the Carribean Tax Havens, Leverhulme for Research on Globalisation and Economic Policy, University of Nottingham, https://www.nottingham.ac.uk/gep/documents/conferences/2009/janconfmalaysia2009/ dsutherland.pdf (26.04. 2016).

Te Velde D.W. (2006), Foreign Direct Investment and Development, An historical perspective, Overseas Development Institute.

„The Guardian” (2016), EU proposals will force multinationals to disclose tax arrangements, 7 February. 
Thorbecke W., Salike N. (2013), Foreign Direct Investment in East Asia, RIETI Policy Discussion Paper Series 13-P-003.

UNCTAD (2001), World Investment Report 2001. Promoting Linkages, New York and Geneva.

UNCTAD (2002), World Investment Report 2002. Transnational Corporations and Export Competitiveness, New York and Geneva.

UNCTAD (2012), World Investment Report 2012. Towards a New Generation of Investment Policies, UNCTAD, New York and Geneva.

UNCTAD (2014), World Investment Prospect Survey 2014-2016, NewYork-Geneva.

UNCTAD (2015a), World Investment Report 2015. Reforming International Investment Governance, NewYork-Geneva.

UNCTAD (2015b), World Investment Report 2015: Annex Tables, http://unctad.org/en/Pages/ DIAE/World\%20Investment\%20Report/Annex-Tables,aspx (15.04.2016).

UNCTAD (2016), Global Investment Trend Monitor, nr 22, 20 January.

Warżała R. (2013), Foreign Direct Investment Flows in the Period of World Economic Crisis, $1^{\text {st }}$ Annual International Interdisciplinary Conference, AIIC 2013, Azores, Portugal, 2324 April.

Wawrzyniak D. (2013), Wpływ opodatkowania przedsiębiorstw na lokalizację bezpośrednich inwestycji zagranicznych $w$ krajach Unii Europejskiej, Wydawnictwo Uniwersytetu Łódzkiego, Łódź.

WB (2016), databank.worldbank.org/ (12.04.2016).

WEF (2013), Foreign Direct Investment as a Key Driver for Trade, Growth and Prosperity: The Case for Multilateral Agreement on Investment, World Economic Forum, Switzerland.

What Did We Learn From the Dotcom Stock Bubble of 2000, „Time” 2015, 12 March, http://time.com/3741681/2000-dotcom-stock-bust/ (16.04.2016).

WTO (2016), Regionalism: friends or rivals?, Geneva: World Trade Organization, https://www.wto.org/english/thewto_e/whatis_e/tif_e/bey1_e.htm (7.04. 2016).

\section{TAX ASPECTS OF THE FLOWS OF FOREIGN DIRECT INVESTMENT ON A GLOBAL SCALE}

A b stract. The article raises issues related to foreign direct investment (FDI) flows on a global scale in the years 1990 to 2014. The paper presents streams and inflow of resources and the tide of these investments, taking into account the distinction between developed countries, developing and transforming their economies. Particularly attention was given to the debate that revolves around tax issues relating to the activities of TNCs, taking up the FDI. These entities in order to achieve high rates of return on investment and maximize profits apply practices that contribute to the reduction of budgetary receipts in both host countries as well as home countries actions aimed at the stem the reduction of taxable income and move to countries with low tax rates, with a view to tax optimization.

K e y w o r d s: foreign direct investment, transnational corporations, global economy, tax optimization. 